\title{
Innovation cooperation in East and West Germany: A study on regional and technological impact
}

\author{
Uwe Cantner $^{\mathrm{a}}$ \\ Alexander Giebler ${ }^{\mathrm{b}}$ \\ Jutta Günther ${ }^{\mathrm{c}}$ \\ Maria Kristalova $^{\mathrm{d}}$ \\ Andreas Meder ${ }^{\mathrm{e}}$
}

\begin{abstract}
${ }^{a}$ Friedrich Schiller University Jena, Department of Economics and Business Administration, Carl-Zeiss-Strasse 3, D-07743 Jena, e-mail: uwe.cantner@uni-jena.de, phone: +49 (0)3641 9-43201; University of Southern Denmark, Department of Marketing and Management, I2M Group, Campusveij 55, DK-5230 Odense M.
\end{abstract}

b Halle Institute for Economic Research, Kleine Märkerstraße 8, D-06108 Halle (Saale), email: Alexander.Giebler@iwh-halle.de, phone: +49(0)345 7753794

${ }^{c}$ University of Bremen, Department of Business Studies and Economics, Hochschulring 4, D-28359 Bremen, email: jutta.guenther@uni-bremen.de, phone: +49 (0)421 218-66630; National Research University Higher School of Economics Moscow, Research Laboratory for Economics of Innovations, Institute for Statistical Studies and Economics of Knowledge

${ }^{\mathrm{d}}$ University of Bremen, Department of Business Studies and Economics, Hochschulring 4, D-28359 Bremen, email: maria.kristalova@uni-bremen.de, phone: +49 (0)421 218-66638

e Thuringian Ministry of Economics, Science and Digital Society, Max-Reger-Straße 4-8, D-99096 Erfurt, eMail: andreas.meder@tmwat.thueringen.de, phone: +49 (0)361 3797311

Abstract: In this paper we investigate the impact of regional and technological innovation systems on innovation cooperation. We develop an indicator applicable to regions, which demonstrates the relative regional impact on innovation cooperation. Applying this method to German patent data, we find that regional differences in the degree of innovation cooperation do not only depend on the technology structure of a region but also on specific regional effects. High-tech oriented regions, whether east or west, are not automatically highly cooperative regions. East German regions have experienced a dynamic development of innovation cooperation since re-unification in 1990. Their cooperation intensity remains higher than in West German regions.

JEL classification: O31, P25, Q55

Keywords: regional innovation system, technological innovation system, innovation cooperation, Germany

Publication information: This article was published as Cantner, U., Giebler, A., Günther, J., Kristalova, M., \& Meder, A. (2018). Innovation cooperation in East and West Germany: A study on the regional and technological impact. International Journal of Computational Economics and Econometrics, 8(3-4), 242-279, DOI:

https://doi.org/10.1504/IJCEE.2018.096360. 


\section{INTRODUCTION}

Innovations often take place collectively when different actors cooperate in order to create something new (Allen 1983). Over the last decades, innovation cooperation activities ${ }^{\mathrm{i}}$ have increased strongly as a real phenomenon (Hagedoorn 2002) and many empirical studies deal with their economic effects (Belderbos et al. 2004, Oerleman/Meeus 2000).

From the resource-based view of a firm, actors engage in cooperation to share the costs and risks of innovation activities and to get access to external knowledge (Mowery et al. 1998, Combs/Ketchen 1999, Das/Teng 2000). Literature in the field of innovation economics points to the importance of networks of innovators in this context (Pyka/Küppers 2002, Pyka 2007). These networks of innovators are subject to a systemic perspective on innovation processes.

The systemic perspective emphasizes knowledge interactions between different types of actors belonging to a system which in terms of borders can be nationally, technologically or regionally defined. The common feature is that cooperation takes place in a certain institutional setting. The differentiation between national, regional, and technological or sectoral systems is a theoretical construct suitable for studying certain phenomena within these frameworks. Empirical literature provides insights into the impact of national innovation systems on technological performance (Nelson 1993). Studies based on technological innovation systems typically refer to certain sectors or technologies (e.g. MacKelvey 1996, Miyazaki/Islam 2007), and there are many empirical analyses pertaining to regional innovation systems (e.g. Asheim/Isaksen 1997, Morgan 1999).

We will contribute to literature in innovation economics by going beyond the perspective of a single innovation system. Our theoretical perspective is that innovative actors are 
simultaneously exposed to several innovation systems at the national, technological and regional level. Any of these systems represents specific conditions for innovation cooperation. As outlined in more detail below, we will particularly focus on technological and regional innovation systems.

In the empirical study, we will analyse the development of innovation cooperation in East and West German regions (ROR) using patent data from the time period after re-unification. Analogous to the Federal Republic of Germany (FRG), innovation cooperation also existed in the German Democratic Republic (GDR). However in case of the GDR, it was subject to central planning (Meske 1993) and did not exist in a dynamic Schumpeterian sense of 'creative destruction'. Spontaneous innovation throughout space and technologies was not part of the socialist system (Kornai 1992, 292ff). While technological development was paid attention to from a strategic perspective (Meske 2004), regional development was of no particular concern in a system of central planning. Thus, the locations of technological activity were largely a result of planning even if historically grown technology centres also continued to exist during socialism. What followed after 1989 in East Germany was a tremendous restructuring process through privatisation, liquidation, start-up activity and the complete dissolution of the science system. During the 1990s, innovation was also subject to enormous changes (Brezinski/Fritsch 1995), and existing networks of production fell entirely apart (Albach 1993 and 1995).

With respect to innovation cooperation, existing research shows that since the late 1990s East German companies no longer fall behind their counterparts in the West, although the choice of partners differs (Fritsch 2003, Günther 2004). Large foreign and West-German-owned firms are integrated in innovation networks especially with respect to science organisations (Günther et al. 2008). These studies look at East and West Germany as a whole. Our objective is to go further by using a more extensive regional breakdown, namely 'planning regions', ROR (see section 4). We also find evidence for the importance of public funding for successful 
cooperation in technology-intensive East German regions (Schwartz et al. 2012). While these studies use survey data, which became available in the late 1990s, other empirical studies use patent data and analyse cooperative innovation in selected regions in East Germany. They show the importance of public science organisations for cooperative innovation in regional innovation systems (Graf 2011, Graf/Henning 2009). Others compare selected East and West German regions (Fritsch 2004, Fritsch/Graf 2011), emphasising the institutional conditions for regional innovative performance. Cantner/Graf (2006) analyse the emergence and determinants of cooperation within a successful East German local innovation system.

To date, no empirical study has been conducted which comprehensively investigates the emergence of innovation cooperation in East (and West) German regions after re-unification. 25 years later, this is an appealing research question since regional innovation systems had to be developed from scratch in the East, and the West mostly served as a benchmark. We assume a strong dynamic of cooperation due to exits and entries of actors (Fritsch 2004), re-orientation of remaining actors (Cantner/Graf 2006), and policy support (Schwartz et al. 2012). As a result of transition, technological activities in East Germany nowadays are very weak compared to West Germany, but the industrial structure and density also differ strongly (Kronthaler 2005, Hornych/Schwartz 2009).

The main contribution of this paper is to analyse the emergence of innovation cooperation since the beginning of transition, covering all of East (and West) Germany. For this purpose, this paper focuses on technological and regional aspects of innovation systems, making use of an indicator that shows whether regional factors have an impact on cooperation that is below or above average, controlling for the technological size and structure of a region. We introduce this indicator as an alternative to the simple share of regional cooperation events which ignores the technological dimension, and we make use of long time series data to also compare the cooperation dynamics in East and West Germany. Essentially, we find evidence for a 
continuously high cooperation activity and regional relevance in the East, as well as a much stronger dynamism compared to the West German regions.

In the following we will present the theoretical and methodological framework (section 2). Based on this, the indicator to measure innovation cooperation at a regional level will be developed (section 3). Section 4 presents the data base, followed by empirical results (section 5). Section 6 will discuss the results, limitations and further research.

\section{THEORETICAL AND METHODOLOGICAL CONSIDERATIONS}

In the literature on technological change, the aspect of collective innovation is taken up by the systemic approach, which distinguishes between different types of 'systems'. Both the elements and the relationships between them constitute the system as a whole. The attributes, as described by Carlsson et al. (2002), define the characteristics of a system. The boundaries of a system separate the system from the rest of the world.

These system considerations have been applied to innovation in the respective innovation system literature, considering innovation as an evolutionary process (Edquist 2004). Here innovations are stimulated by factors internal as well as external to actors (Doloreux \& Parto 2005). With respect to the motivation of individuals to engage in cooperative innovation the main purpose of innovation systems is the generation, diffusion and utilization of knowledge (Lundvall 1992).

\section{Co-existing levels of innovation systems}

Regarding systemic innovation we distinguish between national innovation systems (Freeman et al. 1988, Lundvall 1992), technological systems (Carlsson/Stankiewicz 1991), sectoral innovation systems (Malerba/Orsenigo 1997), regional innovation systems (Cooke 1992), local innovation systems (Breschi/Lissoni 2001), and urban innovation systems (Fischer et al. 2001). 
From an actor's perspective, 'membership' in various innovation systems is possible. A firm located in a certain region can belong to the regional system, one or several technological systems, one or several national innovation systems (multinational firm), etc. These different systems should be considered simultaneously. To accomplish this, we suggest an indicator in section 3 and use it in the empirical analysis of East and West German regions, which is the focus of our paper.

For the analysis of innovation cooperation in German regions, we assume the national innovation system affects all actors the same way. Although we are aware of differences in national innovation systems between countries, we apply this method as a tool for detecting differences between regions within one country. This way we can neglect the framework of a national innovation system and methodological problems that occur by comparing regions located in different countries. Furthermore, we consider the regional dimension on the one hand and the technological dimension on the other as major determinants of cooperative innovation. In doing so, regional, local and urban innovation systems represent regional aspects, while technological and sectoral systems are related to the technological dimension.

\section{Technological dimension}

The concepts of technological innovation systems (Carlsson/Stankiewicz 1991, Carlsson et al. 2002) or sectoral innovation systems (Malerba et al. 1997) point to the fact that actors engaged in the same technology or sector are better able to understand each other and to cooperate. In both concepts, the boundary of the system is justified by the specificity of a sector or technology in terms of a common knowledge base. The idea behind this is that innovative and cooperative behaviour is driven by proximity in their knowledge bases. The concept of technological proximity is rather vague. It has at least three closely interrelated dimensions. First, there is the degree of common understanding in the sense of common or overlapping 
knowledge among actors. Second, understanding is not only related to the type of knowledge but also to the actor's level of knowledge, and hence to the so-called technology gaps between actors. Third, so-called technological regimes characterizing a sector or a technology play a role. Here the degree of appropriability of knowledge, which is never fully complete, determines knowledge spillovers and how cooperation works herein. This degree of appropriability differs among technologies (Doloreux/Parto 2005). Technological proximity defined this way can be used to describe innovation cooperation. Obviously, the higher (lower) the technological proximity the more likely the knowledge of actors is substitutive (complementary).

\section{Regional dimension}

The regional innovation system (RIS) approach derives from the acknowledgement that innovation is often a geographically bounded phenomenon (Asheim/Isaksen 2002, Cooke 1992). The importance of regional resources in stimulating innovative capabilities is a major issue for RIS. It emphasizes geographical proximity as a driving force of cooperation (Fritsch 2001) because of low transaction costs, easier exchange of tacit knowledge, and strengthening of trust. Several empirical studies, however, show that spatial proximity is not always a crucial factor for successful innovation cooperation (Beise/Stahl 1999, Petruzzelli 2011, Slavtchev 2013).

Recent literature on RIS often deals with certain regions and describes their development. In regional science, the existence of a RIS pinpoints innovation cooperation as a main factor of regional economic growth (Fritsch/Mueller 2004). In RIS the boundaries are given by the geographical term 'region'. Following Cooke (2001), a region is a meso-political unit above local governments and below nations, and often has a common culture and history. 
With respect to the subject of this paper, we take into consideration that actors are exposed to the regional innovation system, but simultaneously to technological innovation systems. In doing so, some particularities arise with respect to our subject. The development of cooperation in East and West German regions relates to completely different historical settings and starting conditions in the early 1990s. This needs to be considered when deriving a general working hypothesis out of the theoretical considerations outlined above.

As regards the technological dimension, actors in East and West German regions have been exposed to technological innovation systems very differently. While actors in the West built relations to technologically proximate actors in a market system over decades, East German actors had to get access to these networks after re-unification and establish market-oriented links from scratch in a very uncertain environment. This process was accompanied by many exits and entries of actors and heavy experimentation in all fields of corporate and scientific activity (Grupp/Hinze 1994, Bluhm 1999).

The regional dimension of innovation (cooperation) as discussed above stresses the geographical boundaries of a system, the spatial proximity of actors, and the distinct institutional setting of a region. After re-unification, East German regions, in contrast to the West, were newly defined administratively and suddenly given the chance to develop an independent institutional setting (Fritsch/Graf 2011). This process went back to square one and involved a substantial public innovation policy activity in favour of networks and cooperation (Koschatzky et al. 2001).

Considering the technological and regional aspects under conditions of economic transition, we assume that the heavy structural changes led to a strong dynamism in innovation cooperation in the East, especially throughout the 1990s, and we assume that newly emerging 
regional framework conditions impacted cooperation particularly in the Eastern part of Germany.

We do not derive a theoretical model or specific test hypotheses here, but we use the theoretical considerations to build an indicator on innovation cooperation that refers to the aforementioned considerations. We use the technological dimension as a starting point for the methodological approach (section 3), since the above mentioned literature discusses substantial transitioninduced technological losses and restructurings in the East German regions, which represent an obstacle for catching-up development (Meske 1993, Kronthaler 2005, Hornych/Schwartz 2009). Further, the technological dimension allows a clear-cut and reliable operationalisation strategy (section 4). In the following, we will describe the methodological approach.

\section{THE INDICATOR: RELATIVE REGIONAL IMPACT (RRI)}

In order to empirically investigate our hypothesis, we will go beyond a simple comparison of the regional share of innovation cooperation. The mere share of regional co-innovations would ignore the technological size and structure of a region. Based on the theoretical considerations above, our indicator will control for the technological dimension and measures the remaining regional impact on innovation cooperation.

As developed in section 2, the indicator is based on the assumption that regional and technological innovation systems are the two most important systems in which actors of a particular region are involved, distancing ourselves from the national innovation system. Furthermore, the indicator is based on the assumption that regional and technological factors affect collaboration independently. In other words, we assume that the embeddedness of an actor in the regional system is additive to the embeddedness in the technological system. However, in reality factors interact and lead to complex collaboration structures. In this respect, the index is an analytical tool based on the conception that factors can be looked at separately. 
The methodological approach requires information about an actor's (1) innovation, (2) location, and (3) technology field. Innovations can be observed using information (1) whether they are cooperative or non-cooperative; with (2) and (3) the regional and technological dimension are taken into account. Cooperative innovations are defined as joint innovation activities of at least two different actors. An actor is a firm, a science organization, or an individual person (see section 4).

For these three categories we introduce a formal representation. First, we take into account $n$ innovations indexed by $i \in N=\{1, \ldots, n\}$. The technological space, in which innovations are created, consists of $f$ different technologies indexed by $j \in F=\{1, \ldots, f\}$. Here it is entirely possible that an innovation $i \in N$ is related to more than one technology $j \in F$. The spatial dimension of innovative activities is represented by the regions $r$ indexed by $k \in R=$ $\{1, \ldots, r\}$. Here it is also possible that the R\&D activities for innovation $i$ have taken place in more than one region $k \in R$. This is the case whenever innovation $i$ is the result of a cooperation between actors located in different regions. We also observe a spatial distribution of innovation $i$ when the innovative actors belong to different branches of the same firm which are located in different regions. To distinguish between both possibilities we take information into account regarding whether an innovation $i$ has been developed in cooperation or not. The relationship between innovations, technological field, spatial distribution, and cooperative innovation are formalized as follows. The assignment of all innovations $n$ to the technological fields $f$ is summarized in matrix $\mathbf{A}$. A is a $n \times f$ matrix with a typical element:

$$
\text { (1) } \quad a_{i j}=\left\{\begin{array}{l}
1 \text { if innovation } i \text { is assigned to technology } j \\
0 \text { otherwise }
\end{array}\right.
$$

The spatial distribution of innovations $N$ is represented by the matrix $\mathbf{B}$. B is a $n \times r$ matrix with a typical element: 
(2) $\quad b_{i k}=\left\{\begin{array}{l}1 \text { if innovation } i \text { has been developed by actors located in region } k \\ 0 \text { otherwise }\end{array}\right.$

A spatial distribution of an innovation $i$ occurs whenever different research groups cooperate in a R\&D project resulting in innovation $i$. Whether these research groups work for different actors (e.g. firms or universities) is indicated in vector $\boldsymbol{\gamma} \cdot \boldsymbol{\gamma}$ is a vector of length $n$ with a typical element:

(3) $\quad \gamma_{i}=\left\{\begin{array}{l}1 \text { if innovation } i \text { has been developed by more than one actor } \\ 0 \text { otherwise }\end{array}\right.$

Given this information we propose a method able to identify regional effects on networking behaviour by separating technological effects. Hence, the first step is to account for the technological effects.

\section{The technological dimension of cooperative innovation}

To start with, we identify the propensity to cooperate for each technology. Since innovations are often related to several technologies, we need to know to which degree an innovation $i$ is related to each technology $f$. Hence, for each innovation $i$ we determine weights with respect to each technology. For this purpose, we row-standardize matrix A which contains un-weighted values, as described in the previous section. This operation leads to a $n \times f$ matrix $\mathbf{A}^{w}$ containing the weights by which each technology $j$ contributes to innovation $i$ with a typical element:

$$
\text { (4) } \quad a_{i j}^{w}=\frac{a_{i j}}{\sum_{h=1}^{f} a_{i h}}
$$

The sum of the elements of row $i$ in matrix $\mathbf{A}^{w}$ is necessarily equal to one; all technologies related to innovation $i$ enter with the same weight. 
In order to distinguish between innovative and cooperative activities among technologies, a $n \times n$ diagonal matrix $\boldsymbol{\Gamma}$ with the elements of vector $\boldsymbol{\gamma}$ on the main diagonal is multiplied by matrix $\mathbf{A}^{w}$. The result is a matrix $\mathbf{A}^{w c}$ comprising only the technology weights of cooperative innovations. $\mathbf{A}^{w c}$ is a $n \times f$ matrix with a typical element:

$$
\text { (5) } \quad a_{i j}^{w c}=\sum_{d=1}^{n} \gamma_{i d} a_{d j}^{w}
$$

which is equal to $a_{i j}^{w}$ if $\gamma_{i}=1$ and 0 otherwise.

Matrices $\mathbf{A}^{w}$ and $\mathbf{A}^{w c}$ are used to determine the average cooperation behaviour for each technology. To achieve this, we sum up the elements of each column (technology) in $\mathbf{A}^{w}$ and $\mathbf{A}^{w c}$. In the former case we get an account of the weighted number of innovations related to technology $j$; in the latter case we get an account of the number of related cooperative innovations in that technology. The ratio of both magnitudes indicates the propensity of cooperative innovation in technology $j$. The ratios for all the technologies are included in vector $\mathbf{p}^{c}$.i It is a vector of length $f$ with a typical element:

$$
\text { (6) } \quad p_{j}^{c}=\frac{\sum_{i=1}^{n} a_{i j}^{w c}}{\sum_{i=1}^{n} a_{i j}^{w}}
$$

At this point, however, one has to be careful in interpreting this ratio as a purely technological effect. Since cooperative innovation is affected by both technological as well as regional effects the ratio contains the specific technology-based propensity to cooperate as well as an average influence of regional effects.

\section{The regional dimension of cooperative innovation}

In a second step, we focus on the regional distribution of innovation in general and cooperative innovation in particular. Equivalent to the procedure above, we determine the weights by which an innovation $i$ is related to regions $k \in R$ where the actors innovating $i$ are located. Matrix $\mathbf{B}$ 
contains the unweighted relationships. Its row-standardization delivers the $n \times r$ matrix $B^{w}$ with a typical element:

$$
\text { (7) } \quad b_{i k}^{w}=\frac{b_{i k}}{\sum_{l=1}^{r} b_{i l}}
$$

that contains the weights by which each region contributes to an innovation $i$.

Multiplying matrix $\boldsymbol{\Gamma}$ by matrix $\mathbf{B}^{w}$ leads to the spatial distribution of the cooperative innovations. The resulting matrix $\mathbf{B}^{w c}$ is $n \times r$ with a typical element:

$$
\text { (8) } \quad b_{i k}^{w c}=\sum_{m=1}^{r} \gamma_{i m} b_{m k}^{w}
$$

which is 0 for $\gamma_{i}=0$.

Matrix $\mathbf{B}^{w c}$ contains information about the regional distribution of cooperative innovation independent of whether the cooperation takes place within the region or between regions.

\section{The expected value of regional cooperative innovation}

In a third step, we compute an indicator stating the expected number of cooperative innovations in a region $k$. For this index we take into account the technology-specific propensity for the cooperative innovation of the previous section which also contains the average regional effect. We start by computing the number of innovations of technology $j$ in region $k$. The $r \times f$ matrix $\mathbf{C}^{w}$ - with $r$ rows (regions) and $f$ columns (technology fields) - contains information about the number of innovations that have been developed in technology $j$ by actors from region $k$, i.e. it is simply a matrix which combines technologies and regions. $\mathbf{C}^{w}$ is computed by:

$$
\text { (9) } \quad \mathbf{C}^{w}=\mathbf{B}^{w^{\prime}} \cdot \mathbf{A}^{w}
$$

$\mathbf{B}^{w^{\prime}}$ is the transposed matrix $\mathbf{B}^{w} . \mathbf{C}^{w}$ contains $c_{k j}^{w}$ as a typical element, which stands for a number of innovations in every region allowing for a specific technology and is used to create 
an indicator that we call the 'expected number of cooperative innovation' $\left(e_{k}^{c}\right)$ of region $k$. It indicates how many cooperative innovations are to be expected in region $k$ taking into account the technology-specific propensities $\left(\mathbf{C}^{w}\right)$ for cooperative innovation $p_{j}^{c}$ of those technologies which are used in region $k$. Vector $\mathbf{e}^{c}$ contains the expected number of all cooperative innovations in all regions $k$. It is a vector of length $r$ received by multiplying a matrix of all innovations assigned to respective regions and technologies $\left(\mathbf{C}^{w}\right)$ by a vector of propensity to cooperate in accordance with a technological field $\left(\mathbf{p}^{c}\right)$ with a typical element:

$$
\text { (10) } \quad e_{k}^{c}=\sum_{j=1}^{f} c_{k j}^{w} \cdot p_{j}^{c}
$$

\section{Observed and expected value of regional cooperative innovation}

If cooperative innovations within a region were solely affected by technological determinants (and an average regional effect), the observed number of cooperative innovations has to be identical to the expected number. Thereby we imply that there are no differing regional effects on cooperative innovation. In order to test for this in a final step, for each region $r$ the ratio between the observed and the expected cooperative innovations is determined. To ensure this, we compute the column sum of elements of matrix $\mathbf{B}^{w c}$, which leads to the number of all cooperative innovations observed in each region. For each region we take this sum and divide it by the respective expected number of cooperative innovations $e_{k}^{c}$. The region specific ratios called "relative regional impact" (RRI) are contained by vector $\mathbf{v}$. It is a vector of length $r$ with the typical element:

$$
\text { (11) } \mathbf{v}_{k}=\frac{\sum_{i=1}^{n} b_{i k}^{w c}}{e_{k}^{c}}
$$

This ratio accommodates values between 0 and infinite. With a ratio value of 1 the number of cooperative innovations observed in a region is equal to the expected number. A ratio different from 1 indicates that factors other than technological ones impact the cooperation performance, 
and we ascribe them to the regional innovation system as such. If a region, for example, exhibits an RRI value of 2.0, this region's number of cooperative innovations is twice as high as one could expect regarding the region's technological size and structure (technological innovation system). This higher innovation cooperation activity is regarded here as an expression of a well-functioning and stimulating regional innovation system. For example, the regional innovation system may be characterized by a good infrastructure for inventors, a creative milieu or favourable policy tools. The other way around, an RRI value of 0.5 means that this region's number of cooperative innovations is only half of what one could expect given the technological size and structure of the region. According to our theoretical framework, we ascribe this low RRI value to deficiencies of the regional innovation system.

Additionally, the indicator is independent of the size of a region in terms of the number of cooperative innovations observed. Hence, agglomeration effects or the strength of a regional innovation system that we want to measure cannot simply be attributed to the size of the region, but have to do with an above-average propensity to cooperate. Here, one may alternatively think of the cooperation per innovation ratio as being enough (the share of regional coinnovations over all innovations). While this would be a suitable proxy for the cooperation intensity of a region over all, this ratio would not take into account the differences of cooperative innovation and it would not be related to the specific technologies a region hosts. Since East German regions experienced heavy technological restructuring and losses in the past, we explicitly pay attention to structural differences using the RRI index instead of pure regional co-innovation share. Furthermore, the RRI index includes a standardization with respect to statistical significance, i.e. values of 1.0 signalling an average cooperation activity. Due to these advantages, we suggest the RRI indicator as a means to measure the strength of a regional innovation system and to track its performance over time. To illustrate, we provide an example calculation in Appendix 1. 
Equivalent to the procedure above, we can restrict the analysis to cooperative innovation taking place only within the region. For this purpose, a diagonal $n \times n$ matrix $\tilde{\Gamma}$ which now has elements of vector $\tilde{\boldsymbol{\gamma}}\left(\gamma_{i}=1\right.$ if innovation is developed by multiple actors from the same region and 0 otherwise) is multiplied by matrix $\mathbf{A}^{w}$. The result is a matrix $\widetilde{\mathbf{A}}^{w c}$ comprising only the technology weights of cooperative innovations which have taken place within regions. Using matrices $\mathbf{A}^{w}$ and $\widetilde{\mathbf{A}}^{w c}$, we can then compute the propensity of cooperative innovation represented by vector $\widetilde{\mathbf{p}}^{c}$, which does not only comprise the technological effects but also the average intra-regional effect.

Calculated analogously, matrix $\widetilde{\mathbf{B}}^{w c}$ contains information on cooperative innovations internal to the region. Using matrix $\widetilde{\mathbf{B}}^{w c}$ and vector $\widetilde{\mathbf{p}}^{c}$ one achieves a vector $\tilde{\mathrm{v}}$ which contains the ratio of realized intra-regional cooperation to the expected one. The interpretation is equivalent to the above one. The difference is that in the above we identify regional effects on cooperative innovation in general, whereas here we look at regional effects on intra-regional cooperation.

\section{DATA}

We use patent data to apply the suggested indicator. Although there has been some discussion on the limitations of patents for measuring innovation (e.g., Pavitt 1985, Lall 2003, and Aiginger/Falk 2005) and support of the criticism through empirical evidence (e.g. Aiginger/ Falk 2005), patent data has also been frequently recommended as a proxy for innovative activity (e.g. Archibugi 1992, Dachs/Pyka 2010, Nagaoka/ Motohashi/ Goto 2010, Nesta/Patel 2013 etc.). Moreover, with respect to our research question, patent data is the only data source that allows for the investigation of innovation cooperation over a period going back to the early 1990s.

The data source is the REGPAT database of the OECD (Maraut et al. 2008) which includes applications at the European Patent Office (EPO) and Patent Cooperation Treaty (PCT). Data 
from the German Patent Office (DPMA) could have served as an alternative with a higher number of cases; however, it shows many missing values about the location, which is essential for our study. We compared both data sources for the technological structure and find that they have a very similar structure in terms of distribution among technological fields. Thus, we decided to use REGPAT data which provides sufficient information on the location of actors for the years 1993 to 2010.

To distinguish patent applications by technology, we rely on the information about international patent classification (IPC). Since the IPC is very detailed, we reduce the number of technology classes to 44 categories according to Schmoch et al. (2003). A full list of technology classes used for the current study can be found in Appendix 3. If a patent application lists more than one technology, we use fractional counts with equal weight per technology.

According to the regional dimension, each patent application must be assigned to a region. The patent document allows for two modes of assignment: the address of the applicant or the inventor. The first one has the weakness that actors applying for a patent often state the headquarter address. This can lead to an overestimation of inventive activity in regions with many headquarters. These regions are strongly present in West Germany, while many subsidiaries in East Germany are located. Thus, in this study we use the address(es) of the inventors to assign a patent application to a region. If there are patent applications with more than one inventor, we assign it with the same weight to all regions.

To define a region, we use the concept of planning regions (ROR) which are determined by the Federal Institute for Research on Building, Urban Affairs, and Spatial Development in Germany, taking into account commuter data. The size of the planning regions is between the level of NUTS 2 and NUTS 3. Germany is divided into 96 planning regions considering an 
administrative and functional approach, since the concept accounts for regional labour mobility by commuting activities. A full list of regions can be found in Appendix 4.

Patent data can easily be used to detect innovation cooperation. In this paper, a patent application with at least two different applicants is regarded as a cooperative innovation activity. Since we have no information about the creative share of each applicant we consider their contribution as equal. Furthermore, we consider cooperative innovation between partners within and across regions, since we want to account for cooperation activity in general instead of just intra-regional cooperation.

Our analysis is based on data for the years 1993 to 2010. In order to eliminate a high patent variation over time, we form sub-periods of three years (see Appendix 2). Since the number of patent applications in general and cooperative patent applications in particular was very small in East German regions before 1993, we cannot include earlier time periods.

In general, the number of patent applications increased over time. Only for 2008-2010 does the data show a decline presumably related to the economic crisis. The number of cooperative patent applications follows a similar pattern, whereby the share of cooperative patent applications is clearly higher in East than in the West Germany.

\section{INNOVATION COOPERATION IN EAST AND WEST GERMAN REGIONS}

In the following, we will first only refer to the technological dimension of cooperation investigating the differences in patenting behaviour across technologies, including a comparison between East and West Germany. Following this, we will refer to the regional dimension of cooperation in order to scrutinize regional differences at the level of planning regions, again comparing East and West Germany. Then we will combine the technological and regional dimension calculating and comparing the RRI index. ${ }^{\text {iii }}$ 


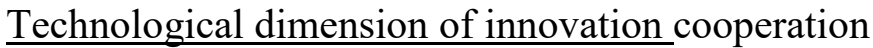

First, we look at the differences in patenting and cooperation between technologies over time. Appendix 5 shows the number of patent applications for each technology and time period $t$. Differences in patent activity are obvious, with most patent applications in technology class 42 (motor vehicles) in all periods, except for 1993 till 1995. Other important technology classes are basic chemicals (class 10), pharmaceuticals (class 13), energy machinery (class 21), special purpose machinery (class 25) and signal transmission, telecommunication (class 35), all with similar growth rates and representing the top technologies over all periods.

Appendix 6 presents information about the number of patent applications, co-applications, and the propensity to cooperate, including the Gini coefficients (Gini 1921) as a measure for the inequality of distribution. We observe an inequality between technologies concerning patent applications and co-applications with Gini coefficients mostly above 0.5 in East and West Germany without major changes over time. ${ }^{\text {iv }}$ Although the findings about the differences between technologies are not particularly surprising, they support our methodical approach which controls for the technological structure of a planning region (ROR).

If we look at the cooperation propensity (share of co-applications over total applications), we recognize that this share is much higher in East than in West Germany. It declines and converges over time but remains stronger in the East (8.4\% versus $4.5 \%$ in $2008-2010)$. Furthermore, in the early 1990 s, cooperation in the East is much more strongly concentrated on certain technological fields (high Gini coefficient) as compared to the West, but it converges over time with a Gini coefficient 0.284 in East and 0.278 in West Germany.

The different cooperation propensities contain the respective technological dimension but also the average regional effect on cooperation, which is the same for all technologies in a given region. This is due to the fact that for the observed co-applications we cannot extract the sheer 
technological effects. More precisely, for each technology this propensity contains the technology specific effect and the average regional effect pertaining to those regions in which the respective technology is located.

\section{$\underline{\text { Regional dimension of innovation cooperation }}$}

Appendix 7 shows how the total number of patents is distributed over the 96 planning regions. Overall, we observe visible differences among regions. There are two outstanding regions, Stuttgart (ROR 810) and Munich (ROR 910), with the highest number of patent applications in each period. Both regions are high-tech oriented, and Munich is also an important location of large universities and public science institutes, including the Fraunhofer and the Max-Planck headquarters.

Appendix 8 presents data about patent applications and co-applications in East and West Germany, including information about the inequality of distribution among regions (Gini coefficient). As in the case of technology fields, the Gini coefficient lies at about 0.5 for both patent applications and co-applications with a tendency of being a bit lower in East than in West Germany. We do not observe strong changes over time.

Thus, in addition to technology related effects on patenting and co-patenting, there are regional effects to be considered in the empirical analysis. As in the case of differences in co-application at the technological level, the observed differences in innovation cooperation on the regional scale include regional effects and the average effect of those technologies contained in the respective region. The next step is to extract the technological effects when looking at regional innovation cooperation.

\section{Differing regional effects on cooperative innovation}


In the final step, we use the RRI index, comparing the observed number of co-applications of a region with the expected number of co-applications. Following section 3 , the ratio between observed and expected co-applications per region, which can be balanced or can be above or below 1.0, indicates an "average status" of a region or an impact of the regional innovation system that advantages or disadvantages innovation cooperation (RRI values higher/lower 1.0).

The RRI index is illustrated for all planning regions in figure 3. The indices differ between regions, which means that there are differing regional effects on innovation cooperation.

Interestingly, as shown in figure 3, the RRI index is clearly higher in East than in West German regions, especially in the early period of transition and throughout the 1990s, whereas it converges later on. ${ }^{\mathrm{v}}$ This result might be an expression of the tremendous restructuring processes in the East German industry and science system. We do not only observe high levels of innovation cooperation but also a strong dynamic of its development within the East German regions. RRI values fluctuate much stronger in East than in West German regions. Throughout the time periods, the variance of the RRI index of an East German region is on average 0,393 while it is 0,177 for a West German region.

The mean RRI values for each region are presented in Appendix 14 including the information on whether an RRI value is significantly higher or lower than one. We run a t test which compares the mean RRI value per region over the six time periods with the hypothetical value of one. In the majority of cases we find statistical significance (see Appendix 14).

FIGURE 3: RRI index of East and West German planning regions (ROR) ${ }^{\mathrm{vi}}$. 


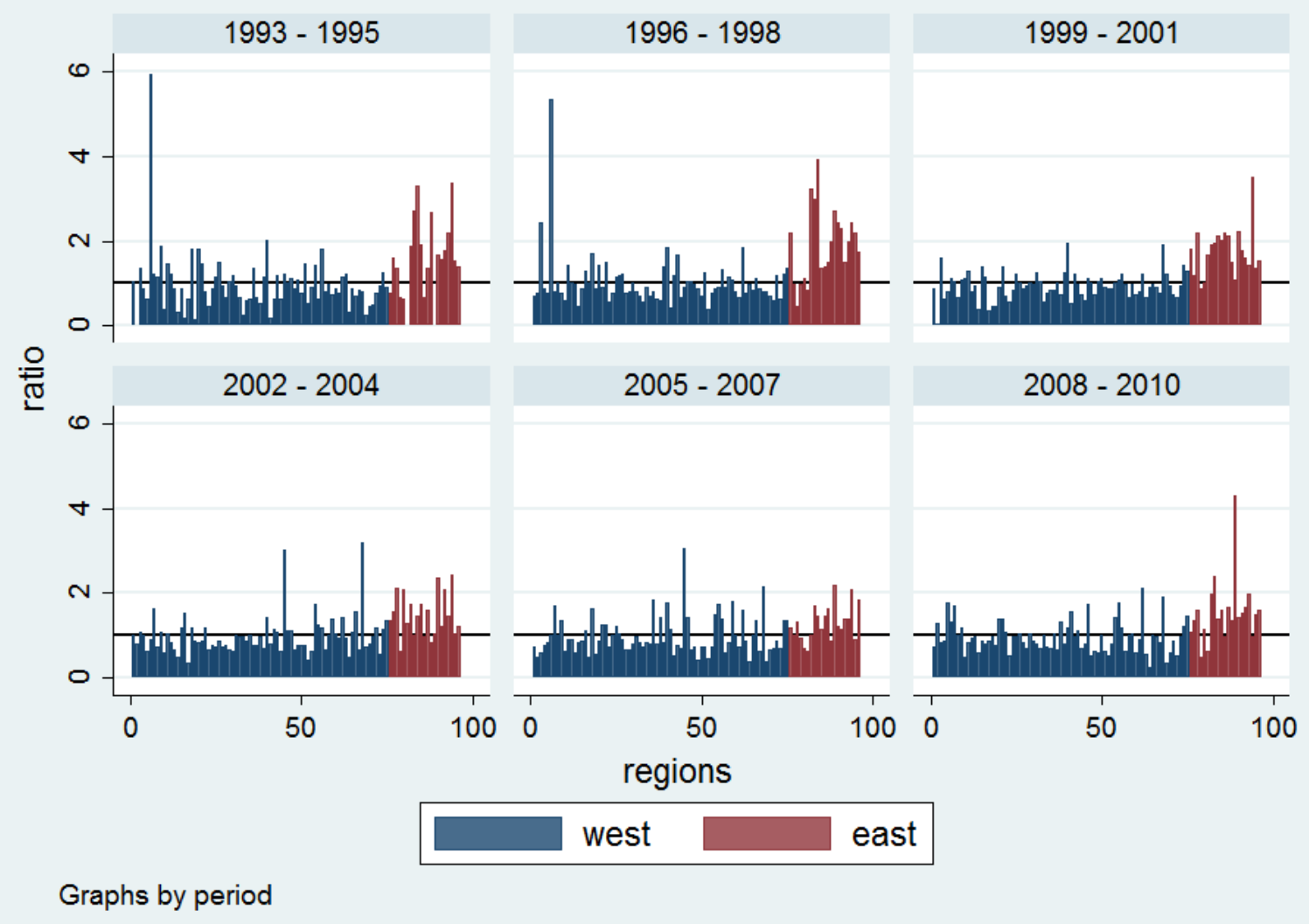

Source: REGPAT database, own calculation. Note: RRI = Relative regional impact

Although some West German regions show very high RRI values in certain time periods with values above five, the average RRI value of East German regions remains higher in every time period. The (in)equality of distribution of the RRI values (Gini coefficient) does not differ substantially between East and West Germany (see Appendix 10).

Finally, Figure 4 below shows a map of the 96 planning regions for the first and last time period. (For maps for the other time periods see Appendix 12) White spots mean that there was no cooperation at all. A darker color indicates a higher RRI value. The maps visualize relatively high RRI values in East Germany. ${ }^{\text {vii }}$ Moreover, regions with a very high innovative activity in terms of number of patent applications, e.g. Munich and Stuttgart, do not necessarily exhibit a high RRI index. It lies between 0.88 and 1.02 in Munich and in Stuttgart between 0.91 and 0.78. In general, there is no correlation between the technological size of a region and a region's RRI value (see Appendix 13). 
FIGURE 4: RRI values for East and West German regions 1993-1995 and 2008-2010.
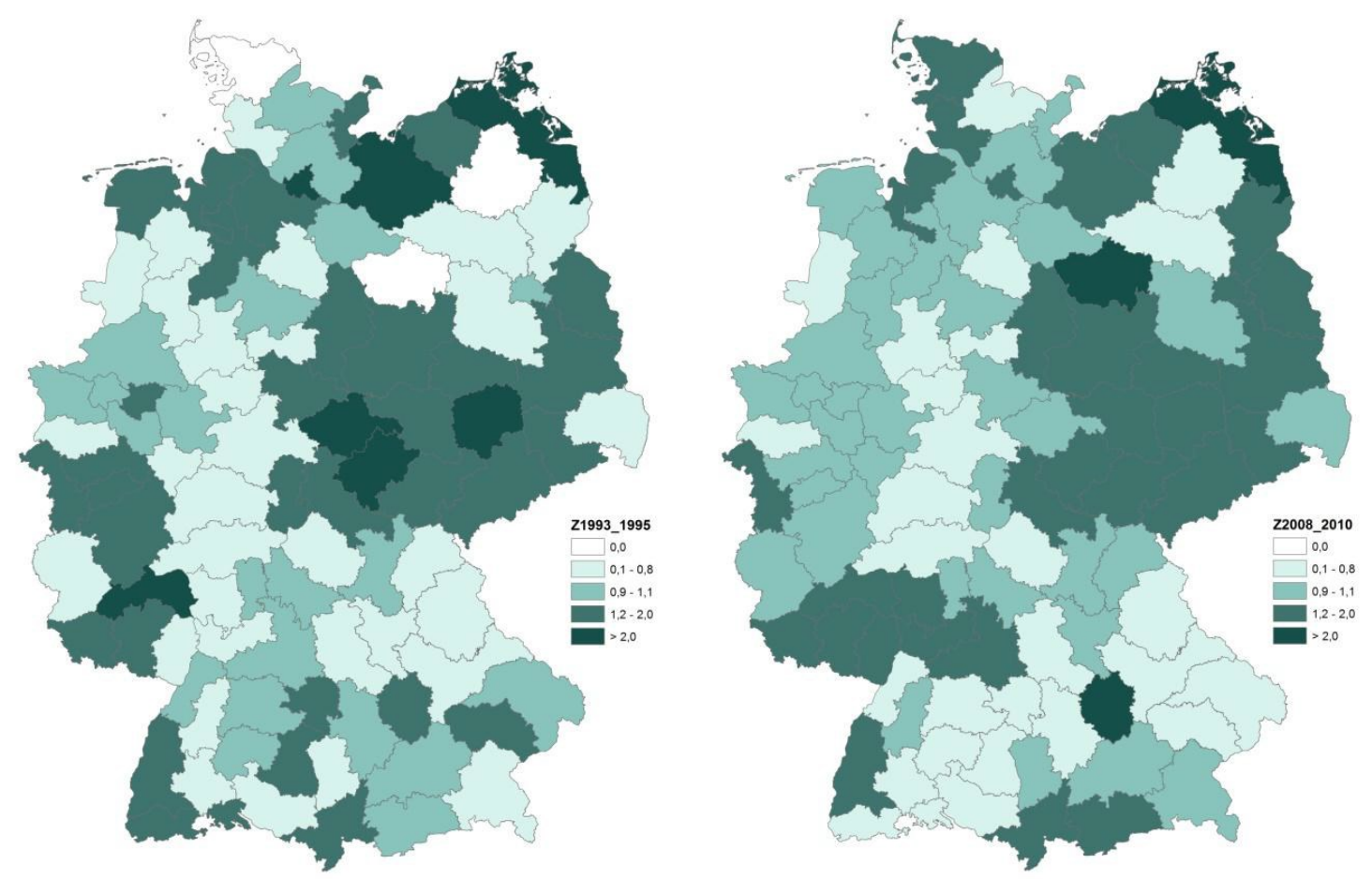

Source: REGPAT database, own calculation.

The results show that East German regions - although weakened technologically and industrially through the transition process - have a stronger cooperation intensity than West German regions throughout the 1990s. Furthermore, the RRI value as an expression of the relative regional impact on cooperation shows that regional framework conditions in many East German regions have a stronger meaning for cooperation as compared to West German regions.

A robustness check confirms our results. Using a more aggregated technology classification (main technology classes according to IPC) leads to RRI values that are very close to the main findings. When we use applicant information as a basis for the regionalization of patents we observe a higher level of RRI values overall, but with East German regions exhibiting higher values than West German regions. ${ }^{\text {viii }}$ Moreover, the higher dynamics of cooperation (variance 
of RRI) as well as higher median values of RRI in the East can be confirmed in the robustness check (see Appendix 15).

Our results are in line with earlier studies (Fritsch 2003, Günther 2004) and patent data for selected East and West German regions (Cantner/Graf 2006). The assumption of "disrupted networks" put forward in earlier literature on production systems (Albach 1993 and 1995) cannot be confirmed. This latter point is rather surprising. It is most probably related to the specific situation of research units in the early stage of transition. These units lost their cooperation partners but had to quickly find new actors to collaborate with under conditions of severe survival pressure.

At first glance, the results are favourable for East German regions since they express a higher innovation cooperation activity (RRI values) as compared to West German regions. However, this must be considered in light of the real structural situation in the two regional parts of Germany. East Germany is characterized by a weak industrial base with many small and medium firms and not many headquarters, while West Germany shows many large companies and headquarters. Actors in East Germany may try to generate economies of scale through cooperation. Whether this will at the end be enough to compensate for the lack of large firms and headquarters is, however, not clear.

\section{DISCUSSION AND CONCLUSION}

Normally, empirical studies on innovation cooperation deal with either the technological or the regional dimension of innovation. Our contribution is an approach that accounts for the simultaneous participation of actors in technological and regional innovation systems. This progress has been made at the expense of some analytical assumptions that must be discussed when using the indicator. A major assumption is that technological and regional factors are independent of each other, which in reality does not apply. In this sense, the indicator is an 
analytical approach that expresses a regional impact below or above average. It can, however, not fully be disentangled from technological (and maybe even further) dimensions. Apart from this, by using patent data, we include only those innovation cooperation events that produce patents. In reality, the knowledge base and its stimulus for cooperation can be much broader.

Still, the index controlling for the technological dimension is of high importance for the subject of this paper, since the Eastern part of Germany is strongly characterized by transition-related technological weaknesses. We contribute to the literature through a comprehensive investigation of the emergence of innovation cooperation since re-unification, including all German regions (ROR) instead of studying selected or single regions, which has been done frequently so far (e.g. Cantner/Graf 2006, Fritsch 2004, Fritsch/Graf 2011, Graf/Henning 2009, Schwartz et al. 2012) or just East and West Germany as a whole (e.g. Günther 2004, Fritsch 2003, Günther et al. 2008).

Furthermore, we show that the dynamic of innovation cooperation within East German regions is much higher, expressed through a strong variation of RRI values in East German regions. This is most probably an expression of the tremendous restructuring and reorientation processes due to the sudden system change. Industry and science organizations experienced ownership changes, liquidations, restructuring etc. Under these circumstances, private persons might have found it attractive to (co-)patent, especially in the early periods of transition in order to secure their intellectual property in times of heavy uncertainty. Furthermore, Graf \& Henning (2009) state that many firms in East Germany are young. If they fail, the patent rights are part of the insolvency volume, which motivates inventors in East Germany to apply as a private person. The structure of applicants as an explanatory factor of differences in cooperation calls for further research considering actors' patenting behaviour. Another limitation of our analysis is the fact that we cannot use the RRI values presented here to make clear-cut statements about the strength or weakness of the respective regional innovation 
system. This is because our calculations relate to innovation cooperation in general instead of intra-regional cooperation in particular. Furthermore, one must discuss the cooperation intensity in light of the general structural conditions of a region under consideration.

Thus, further research could deal with an evaluation oriented assessment of regional innovation systems and would then use the RRI indicator on an intra-regional basis. Considering the high importance of cooperation in innovation policy (Muldur et al. 2006), another important field for further research is the question as to whether and to what degree innovation cooperation (high RRI values) contributes positively to regional economic performance. This is of particular interest for post-transition regions where the problem of network failure or misalignment has been discussed (Varblane et al. 2007; von Tunzelmann 2004). It means that linkages in production and innovation systems might exist, but in an unfavourable or ineffective manner without a positive impact on economic development (von Tunzelmann et al. 2010). With respect to East Germany and new EU member states where innovation policy strongly rests on the support of regional science-industry cooperation, the subject offers much scope for further analyses also taking a European perspective. 


\section{REFERENCES}

Aiginger, K. and Falk, M. (2005) 'Explaining differences in economic growth among OECD countries', Empirica, Vol. 32, No. 1, pp.19-43.

Albach, H. (1993) Zerrissene Netze, eine Netzwerkanalyse des ostdeutschen Transformationsprozesses. Berlin, Ed. Sigma

Albach, H. (1995): The management of transition in East German firms. In: Zeitschrift für Betriebswirtschaft, Special Issue 4/95, 53-83

Allen, R. (1983), 'Collective invention', Journal of Economic Behavior and Organization 4, 124.

Archibugi, D. (1992): Patenting as an indicator of technological innovation: a review. Science and Public Policy, 19, (6) 357-368.

Asheim, B. T.; Isaksen, A. (1997): Location, Agglomeration, and Innovation: Towards Regional Innovation Systems in Norway? In: European Planning Studies, 5 (3), 299-330.

Asheim, B. \& Isaksen, A. (2002) Regional innovation systems: the integration of local sticky and global ubiquitous knowledge, Journal of Technology Transfer.

Beise, M.; Stahl, H. (1999): Public research and industrial innovations in Germany. In: Research Policy, 28 (4), 397-422.

Belderbos, R., Carree, M. \& Lokshin, B. (2004) Cooperative r\&d and firm performance, Research Policy 33(10), 1477-1492.

Bluhm, K. (1999): Zwischen Markt und Politik. Probleme und Praxis von Unternehmenskooperation in der Transitionsökonomie. Opladen: Leske+Budrich. 
Breschi, S. \& Lissoni, F. (2001), 'Knowledge spillovers and local innovation systems: a critical survey, Industrial and Corporate Change 10(4), 975-1005.

Brezinski, H. \& Fritsch, M. (1995): Transformation: The shocking German way. in: MostMost, 5, 1-25.

Cantner, U. \& Graf, H. (2006), 'The network of innovators in jena: An application of social network analysis', Research Policy 35(4), 463-480.

Carlsson, B. \& Stankiewicz, R. (1991) On the nature, function and composition of technological systems', Journal of Evolutionary Economics 1, 45-65.

Carlsson, B., Jacobson, S., Holmen, M. \& Rickne, A. (2002) Innovation systems: analytical and methodological issues, Research Policy 31, 233-245.

Combs, J. \& Ketchen, D. (1999), `Explaning interfirm cooperation and performance: Toward a recounciliation of predictions from the resource-based view and organizational economics', Strategic Management Journal 20, 867-888.

Cooke, P. (1992): Regional innovation systems: Competitive regulation in the new Europe, Geoforum 23, 365-382.

Cooke, P. (2001), Regional innovation systems, clusters, and the knowledge economy', Industrial Corporate and Change 10(4), 945-974.

Dachs, B. and Pyka, A. (2010) 'What drives the internationalisation of innovation? Evidence from European patent data', Economics of Innovation and New Technology, Vol. 19, No. 1, pp.71-86.

Das, T. \& Teng, B. (2000), A resource-based theory of strategic alliances, Journal of Management 26, 31-65. 
Doloreux, D. \& Parto, S. (2005), 'Regional innovation systems: current discourse and unresolved issues', Technology in Society 27(2), 133-153.

Edquist, C. (2004), Systems of innovation - a critical review of the state of the art, in Oxford Handbook of Innovations, Oxford University Press.

Fischer, M., Diez, J. \& Snickars, F. (2001), Metropolitan Innovation Systems; Theory And Evidence From Three Metropolitan Regions In Europe, Springer.

Freedman, D., Thornton, A., Camburn, D., Alwin, D. \& Young-DeMarco, L. (1988), `The life history calender: A technique for collecting retrospective data', Sociological Methodology 18, $37-68$.

Fritsch, M. (2003): Does R\&D Cooperation Behavior Differ between Regions? Industry and Innovation, Vol. 10 (2003), 25-39.

Fritsch, M. (2004), Entrepreneurship, entry and performance of new business compared in two growth regimes: East and West Germany, Journal of Evolutionary Economics 14(5), 525-542.

Fritsch, M.; Mueller, P. (2004), Regional growth regimes revisited: the case of West Germany, Freiberger Arbeitspapiere 2004-06.

Fritsch, M. (2001): Co-operation in Regional Innovation Systems, Regional Studies 35, 297307.

Fritsch, M.; Graf, H. (2011), How sub-national conditions affect regional innovation systems: The case of the two Germanys, Papers in Regional Science, 90(2), 331-353.

Gini, C. (1921), Measurement of inequality of income, Economic Journal 31, 22-43.

Graf, Holger and Tobias Henning (2009), Public Research in Regional Networks of Innovators: A Comparative Study of Four East-German Regions, Regional Studies, 43(10), 1349-1368. 
Graf, H. (2011), Gatekeepers in regional networks of innovators, Cambridge Journal of Economics, 35(1), 173-198.

Grupp, H.; Hinze, S. (1994): International Orientation, Efficiency of and Regard for Research in East and West Germany: A Bibliometric Investigation of Aspects of Technology Genesis in the United Germany, in: Scientometrics, 29(1), 83-113.

Günther, J. (2004): Innovation cooperation: experiences from East and West Germany, in: Science and Public Policy, 31(2), 151-158.

Günther, J.; Stephan, J.; Jindra, B. (2008): Foreign Subsidiaries in the East German Innovation System - Evidence from manufacturing industries, in: Applied Economics Quarterly, 54 (59), $137-165$

Hagedoorn, J. (2002): Inter-firm R\&D partnership: an overview of major trends and patterns since 1960. Research Policy 31(4), 477-492.

Hornych, C., Schwartz, M. (2009): Industry Concentration and Regional Innovative Performance - Empirical Evidence for Eastern Germany, Post-Communist Economies, 21 (4), $513-530$

Kornai, J. (1992): The Socialist System. The Political Economy of Communism, Princeton: Princeton University Press.

Koschatzky, K.; Kulicke M.; Zenker, A. (eds.) (2001): Innovation Networks. Concepts and Challenges in the European Perspective. Heidelberg, New York: Physica.

Kronthaler, F. (2005): Economic Capability of East German Regions: Results of a Cluster Analysis. Regional Studies, 39 (6), 741-752. 
Lall, S. (2003) 'Indicators of the relative importance of IPRs in developing countries', Research Policy, Vol. 32, No. 9, pp.1657-1680.

Lundvall, B. (1992), National Systems of Innovation: Towards a theory of innovation and interactive learning, Pinter.

Maraut, S.; Dernis, H.; Webb, C.; Spiezia, V.; Guellec, D. (2008): The OECD REGPAT Database: A Presentaiton. STI Working Paper, 2008/2.

McKelvey, M. (1996): Evolutionary Innovations. The Business of Biotechnology. Oxford University Press.

Malerba, F. \& Orsenigo, L. (1997), Technological regimes and sectoral patterns of innovative activities', Industrial Corporate and Change 6(1), 83-117.

Malerba, F., Orseniga, L. \& Peretto, P. (1997), Persistence of innovative activities, sectoral patterns of innovation and international technological specialization', International Journal of Industrial Organization 15, 801-826.

Meske, W. (1993): The Restructuring of the East German Research System - a Provisional Appraisal. In: Science and Public Policy, Vol. 20, 298-312.

Meske, W. (2004) (ed.): From system transformation to European integration. Science and technology in Central and Eastern Europe at the beginning of the 21st century. Münster: LitVerlag.

Miyazaki, K., Islam, N. (2007): Nanotechnology systems of innovation-An analysis of industry and academia research activities, Technovation 27 (11), 661-675. 
Morgan, K. (1999): Reversing Attrition? The Auto-Cluster in Baden-Württemberg. In: Barnes, T. J.; Gertler, M. S. (eds.): The New Industrial Geography: Regions, Regulation, and Institutions. London: Routledge, 74-97.

Mowery, D., Oxley, J. \& Silverman, B. (1998), Technological overlap and interfirm cooperation: implications for the ressource-based view of the firm, Research Policy 27(5), 507523.

Muldur, U., Corvers, F., Delanghe, H., Dratwa, J., Heimberger, D., Sloan, B., Vanslembrouck, S. (2006): A New Deal for an Effective European Research Policy. Springer.

Nagaoka, S., Motohashi, K. and Goto, A. (2010) 'Patent statistics as an innovation indicator', in Hall, B.H. and Rosenberg, N. (Eds.): Handbook of the Economics of Innovation, Vol. 2, 1st ed., Elsevier, pp.1083-1127, https://www.elsevier.com/books/handbook-of-the-economicsof-innovation/hall/978-0-444-53609-9 (Accessed 15 January, 2017).

Nelson, R. R. (1993): National Innovation Systems: A comparative Analysis. University Press, Oxford.

Nesta, L.; Patel, P. (2013): National Patterns of Technology Accumulation: Use of Patent Statistics, in Handbook of Quantitative Science and Technology Research. The Use of Publication and Patent Statistics in Studies on S\&T Systems, H. F. Moed, W. Glänzel, \& U. Schmoch, eds., 531-551.

Oerleman, L. \& Meeus, M. (2000): Firm behaviour and innovative performance: An empirical exploration of the selection-adaptation debate, Research Policy 29, 41-58.

Pavitt, K. (1985) 'Patent statistics as indicators of innovative activities: possibilities and problems', Scientometrics, Vol. 7, No. 1-2, pp.77-99 
Petruzzelli, A. M. (2011): The impact of technological relatedness, prior ties, and geographical distance on university-industry collaborations: A joint-patent analysis, Technovation, 31(7), 309-319.

Pyka, A., Küppers, G. (ed.) (2002): Innovation networks - theory and practice. Cheltenham UK/Nothhampton USA: Edward Elgar.

Pyka, A. (2007): Innovation Networks. In: Hanusch, H.; Pyka, A. (eds.): Elgar Companion to Neo-Schumpeterian Economics. Cheltenham, Northampton: Edward Elgar, 360-376.

Schmoch, U., Laville, F., Patel, P. \& Frietsch, R. (2003), Linking technology areas to industrial sectors, Final Report to the European Commission DG Research .

Schwartz, M.; Peglow, F.; Fritsch, M.; Günther, J. (2012): What Drives Innovation Output from Subsidized R\&D Cooperation? Project-level Evidence from Germany, in: Technovation, Vol. 32 (6), 2012, 358-369.

Slavtchev, V. (2013): Proximity and the Transfer of Academic Knowledge: Evidence from the Spatial Pattern of Industry Collaborations of East German Professors. Regional Studies, 47(5), 686-702.

Varblane, U.; Dyker, D.; Tamm, D.; von Tunzelmann, N. (2007): Can the national innovation systems of the new EU member-states be improved? In: Post-Communist Economies, Vol. 19 (4), 399-416.

Von Tunzelmann, N. (2004): Network alignment in the catching-up economies of Europe. In: McGowan, F.; Radosevic, S.; von Tunzelmann, N. (eds.): The emerging industrial structure of the wider Europe, 23-37. 
Von Tunzelmann, N.; Günther, J.; Wilde, K.; Jindra, B. (2010): Interactive dynamic capabilities and regenerating the East German innovation system. In: Contributions to Political Economy, 29 (1), 87-110. 
APPENDIX 1: Illustration of the RRI indicator

The RRI indicator can be illustrated on the following example calculation.

Basic data for the example:

\begin{tabular}{c|c|c|c}
\hline Innovation & Technology field & Region & Cooperation innovation \\
\hline Innovation 1 & TF1 & R1 and R2 & Coop \\
Innovation 2 & TF1 and TF2 & R1 and R2 & Coop \\
Innovation 3 & TF2 & R2 & \\
\hline
\end{tabular}

Note: $\mathrm{TF}=$ technology field, $\mathrm{R}=$ region

We consider three innovations, hence $i=\{1 ; 2 ; 3\}$ and $n=3$. These innovations are related to two technologies (TF1 and TF2), so that $j=\{1 ; 2\}$ and $f=2$. The inventors are located in two different regions (R1 and R2), hence $k=\{1 ; 2\}$ and $r=2$. Two of those three innovations are generated by two actors and are identified as cooperative innovation. We do not consider the case of intra-regional cooperation but the more general case. With respect to this example, matrix $\mathbf{A}$ is a $3 \times 2$-matrix:

$$
\mathbf{A}=\left(\begin{array}{ll}
1 & 0 \\
1 & 1 \\
0 & 1
\end{array}\right)
$$

Matrix $\mathbf{B}$ is a $3 \times 2$ matrix:

$$
\mathbf{B}=\left(\begin{array}{ll}
1 & 1 \\
1 & 1 \\
0 & 1
\end{array}\right)
$$

Vector $\boldsymbol{\gamma}$ indicating whether innovation $i$ is cooperatively generated contains the following elements:

$$
\gamma=\left(\begin{array}{l}
1 \\
0 \\
1
\end{array}\right)
$$


With these data, first the technological dimension is analyzed. The absolute values in matrix $\mathbf{A}$ are weighted by the number of technologies $j$ innovation $i$ is related to. The outcome is matrix $\mathbf{A}^{w}$ :

$$
\mathbf{A}^{w}=\left(\begin{array}{cc}
1 & 0 \\
0.5 & 0.5 \\
0 & 1
\end{array}\right)
$$

Proceeding the same way for cooperative innovations $\left(\gamma_{i}=1\right)$ leads to the matrix $\mathbf{A}^{w c}$ :

$$
\mathbf{A}^{w c}=\left(\begin{array}{ll}
1 & 0 \\
0 & 0 \\
0 & 1
\end{array}\right)
$$

The two matrices contain information about the relationship between all innovations on the one hand and cooperative innovations on the other hand to the two technology fields. Both matrices are used to compute the propensity for cooperative innovation in each of the two technologies by dividing each column sum of $\mathbf{A}^{w c}$ by the respective column sum of $\mathbf{A}^{w}$. The results are contained in vector $\mathbf{p}^{c}$ :

$$
\mathbf{p}^{c}=\left(\begin{array}{l}
0.67 \\
0.67
\end{array}\right)
$$

Here, for both technologies, we get the same propensity to cooperate $(0.67)$.

In a second step, the regional dimension of innovation and cooperative innovation is considered. We obtain $\mathbf{B}^{w}$ for the regional distribution of all innovations and $\mathbf{B}^{w c}$ for the cooperative innovations:

$$
\mathbf{B}^{w}=\left(\begin{array}{cc}
0.5 & 0.5 \\
0.5 & 0.5 \\
0 & 1
\end{array}\right) \quad \mathbf{B}^{w c}=\left(\begin{array}{cc}
0.5 & 0.5 \\
0 & 0 \\
0 & 1
\end{array}\right)
$$


The third step sets into relation the technological and the spatial dimension using all innovations. The result of multiplying the transpose of matrix $\mathbf{B}^{w^{\prime}}$ and $\mathbf{A}^{w}$ is shown in matrix $\mathbf{C}^{w}$ which has the dimension $2 \times 2$ (2 regions and 2 technologies):

$$
\mathbf{C}^{w}=\left(\begin{array}{ll}
0.75 & 0.25 \\
0.75 & 1.25
\end{array}\right)
$$

The expected share of cooperative innovations for each region is computed by multiplying matrix $\mathbf{C}^{w}$ by the vector of the cooperation propensity $\mathbf{p}^{c}$. The result is a vector $\mathbf{e}^{c}$ which has a length of 2 according to the number of regions:

$$
\mathbf{e}^{c}=\left(\begin{array}{l}
0.67 \\
1.33
\end{array}\right)
$$

According to the technological classification of all innovations in region $\mathrm{R} 1$ and $\mathrm{R} 2$, the expected cooperation value in region 1 is twice (1.33) the value of region 2 (0.67). Finally, the observed number of cooperative innovations for each region $k$, indicated through matrix $\mathbf{B}^{w c}$, is related to these values; for region 1 this is 0.5 and for region 2 we get 1.5 . The final result are RRI values included in $\mathbf{v}$ :

$$
\mathbf{v}=\left(\begin{array}{l}
0.75 \\
1.25
\end{array}\right)
$$

In our example in region 1, the observed cooperative innovations are less than one could expect $(0.5 / 0.67=0.75)$ according to its patent application behaviour among all technologies, whereas in region 2 observed cooperative innovations exceed their expected value $(1.5 / 1.33=1.25)$. Within our theoretical context this suggests that for region 2 there is a working regional effect fostering cooperative innovation above the average; in region 1, by contrast, factors seem to be present that are not fostering or even preventing cooperative innovation. 
APPENDIX 2: Descriptive statistics of the data base

\begin{tabular}{|c|c|c|c|c|c|c|c|c|c|}
\hline \multirow[t]{2}{*}{$\begin{array}{l}\text { Time } \\
\text { period }\end{array}$} & \multicolumn{3}{|c|}{ Number of patent applications } & \multicolumn{3}{|c|}{$\begin{array}{c}\text { Number of cooperative } \\
\text { patent applications }\end{array}$} & \multicolumn{3}{|c|}{$\begin{array}{l}\text { Cooperative patent } \\
\text { applications (\%) }\end{array}$} \\
\hline & Total & East & West & Total & East & West & Total & East & West \\
\hline $1993-1995$ & 39406.55 & 1106.14 & 38300.41 & 2107.90 & 103.30 & 2004.59 & 5.35 & 9.34 & 5.23 \\
\hline $1996-1998$ & 56646.39 & 2000.86 & 54645.53 & 2850.53 & 188.33 & 2662.20 & 5.03 & 9.41 & 4.87 \\
\hline $1999-2001$ & 72077.29 & 3228.74 & 68848.55 & 3463.81 & 301.45 & 3162.36 & 4.81 & 9.34 & 4.59 \\
\hline $2002-2004$ & 76214.36 & 3664.58 & 72549.78 & 3557.92 & 269.62 & 3288.30 & 4.67 & 7.36 & 4.53 \\
\hline $2005-2007$ & 86072.62 & 4659.10 & 81413.52 & 4130.94 & 300.43 & 3830.51 & 4.80 & 6.45 & 4.71 \\
\hline $2008-2010$ & 76962.24 & 4524.73 & 72437.51 & 3614.43 & 348.72 & 3265.71 & 4.70 & 7.71 & 4.51 \\
\hline
\end{tabular}

Source: REGPAT database, own calculation. 
APPENDIX 3: List of technology classes used in the study.

\begin{tabular}{|c|c|}
\hline Class No. & Class description \\
\hline 1 & Food, beverages \\
\hline 2 & Tobacco products \\
\hline 3 & Textiles \\
\hline 4 & Wearing apparel \\
\hline 5 & Leather articles \\
\hline 6 & Wood products \\
\hline 7 & Paper \\
\hline 8 & Publishing \\
\hline 9 & Petroleum products, nuclear fuel \\
\hline 10 & Basic chemical \\
\hline 11 & Pesticides, agro-chemical products \\
\hline 12 & Paints, varnishes \\
\hline 13 & Pharmaceuticals \\
\hline 14 & Soaps, detergents, toilet preparations \\
\hline 15 & Other chemicals \\
\hline 16 & Man-made fibres \\
\hline 17 & Rubber and plastics products \\
\hline 18 & Non-metallic mineral products \\
\hline 19 & Basic metals \\
\hline 20 & Fabricated metal products \\
\hline 21 & Energy machinery \\
\hline 22 & Non-specific purpose machinery \\
\hline 23 & Agricultural and forestry machinery \\
\hline 24 & Machine-tools \\
\hline 25 & Special purpose machinery \\
\hline 26 & Weapons and ammunition \\
\hline 27 & Domestic appliances \\
\hline 28 & Office machinery and computers \\
\hline 29 & Electric motors, generators, transformers \\
\hline 30 & Electric distribution, control, wire, cable \\
\hline 31 & Accumulators, battery \\
\hline 32 & Lighting equipment \\
\hline 33 & Other electrical equipment \\
\hline 34 & Electronic components \\
\hline 35 & Signal transmission, telecommunications \\
\hline 36 & Television and radio receivers, audiovisual electronics \\
\hline 37 & Medical equipment \\
\hline 38 & Measuring instruments \\
\hline 39 & Industrial process control equipment \\
\hline 40 & Optical instruments \\
\hline 41 & Watches, clocks \\
\hline
\end{tabular}




\begin{tabular}{|l|l|}
\hline 42 & Motor vehicles \\
\hline 43 & Other transport equipment \\
\hline 44 & Furniture, consumer goods \\
\hline
\end{tabular}

Source: Own presentation based on Schmoch et al. (2003)

APPENDIX 4: List of regions used in the study.

\begin{tabular}{|c|l|}
\hline ROR No. & Name of ROR \\
\hline 101 & Schleswig-Holstein Mitte \\
\hline 102 & Schleswig-Holstein Nord \\
\hline 103 & Schleswig-Holstein Ost \\
\hline 104 & Schleswig-Holstein Süd \\
\hline 105 & Schleswig-Holstein Süd-West \\
\hline 201 & Hamburg \\
\hline 301 & Braunschweig \\
\hline 302 & Bremen-Umland \\
\hline 303 & Bremerhaven \\
\hline 304 & Emsland \\
\hline 305 & Göttingen \\
\hline 306 & Hamburg-Umland-Süd \\
\hline 307 & Hannover \\
\hline 308 & Hildesheim \\
\hline 309 & Lüneburg \\
\hline 310 & Oldenburg \\
\hline 311 & Osnabrück \\
\hline 312 & Ost-Friesland \\
\hline 313 & Südheide \\
\hline 401 & Bremen \\
\hline 501 & Aachen \\
\hline 502 & Arnsberg \\
\hline 503 & Bielefeld \\
\hline 504 & Bochum/Hagen \\
\hline 505 & Bonn \\
\hline 506 & Dortmund \\
\hline 507 & Duisburg/Essen \\
\hline 508 & Düsseldorf \\
\hline 509 & Emscher-Lippe \\
\hline 510 & Köln \\
\hline 511 & Münster \\
\hline 512 & Paderborn \\
\hline 513 & Siegen \\
\hline 601 & Mittelhessen \\
\hline 602 & Nordhessen \\
\hline 603 & Osthessen \\
\hline & \\
\hline
\end{tabular}




\begin{tabular}{|r|l|}
\hline 604 & Rhein-Main \\
\hline 605 & Starkenburg \\
\hline 701 & Mittelrhein-Westerwald \\
\hline 702 & Rheinhessen-Nahe \\
\hline 703 & Rheinpfalz \\
\hline 704 & Trier \\
\hline 705 & Westpfalz \\
\hline 801 & Bodensee-Oberschwaben \\
\hline 802 & Donau-Iller (BW) \\
\hline 803 & Franken \\
\hline 804 & Hochrhein-Bodensee \\
\hline 805 & Mittlerer Oberrhein \\
\hline 806 & Neckar-Alb \\
\hline 807 & Nordschwarzwald \\
\hline 808 & Ostwürttemberg \\
\hline 809 & Schwarzwald-Baar-Heuberg \\
\hline 810 & Stuttgart \\
\hline 811 & Südlicher Oberrhein \\
\hline 812 & Unterer Neckar \\
\hline 901 & Allgäu \\
\hline 902 & Augsburg \\
\hline 903 & Bayerischer Untermain \\
\hline 904 & Donau-Iller (BY) \\
\hline 905 & Donau-Wald \\
\hline 906 & Industrieregion Mittelfranken \\
\hline 907 & Ingolstadt \\
\hline 908 & Landshut \\
\hline 909 & Main-Rhön \\
\hline 910 & München \\
\hline 911 & Oberfranken-Ost \\
\hline 912 & Oberfranken-West \\
\hline 913 & Oberland \\
\hline 914 & Oberpfalz-Nord \\
\hline 915 & Regensburg \\
\hline 916 & Südostoberbayern \\
\hline 917 & Westmittelfranken \\
\hline 918 & Würzburg \\
\hline 1001 & Saar \\
\hline & Berlin \\
\hline 1201 & Havelland-Fläming \\
\hline & Oausitz-Spreewald \\
\hline
\end{tabular}




\begin{tabular}{|l|l|}
\hline 1301 & Mecklenburgische Seenplatte \\
\hline 1302 & Mittleres Mecklenburg/Rostock \\
\hline 1303 & Vorpommern \\
\hline 1304 & Westmecklenburg \\
\hline 1401 & Oberes Elbtal/Osterzgebirge \\
\hline 1402 & Oberlausitz-Niederschlesien \\
\hline 1403 & Südsachsen \\
\hline 1404 & Westsachsen \\
\hline 1501 & Altmark \\
\hline 1502 & Anhalt-Bitterfeld-Wittenberg \\
\hline 1503 & Halle/S. \\
\hline 1504 & Magdeburg \\
\hline 1601 & Mittelthüringen \\
\hline 1602 & Nordthüringen \\
\hline 1603 & Ostthüringen \\
\hline 1604 & Südthüringen \\
\hline
\end{tabular}

APPENDIX 5: Number of patent applications by technology fields.

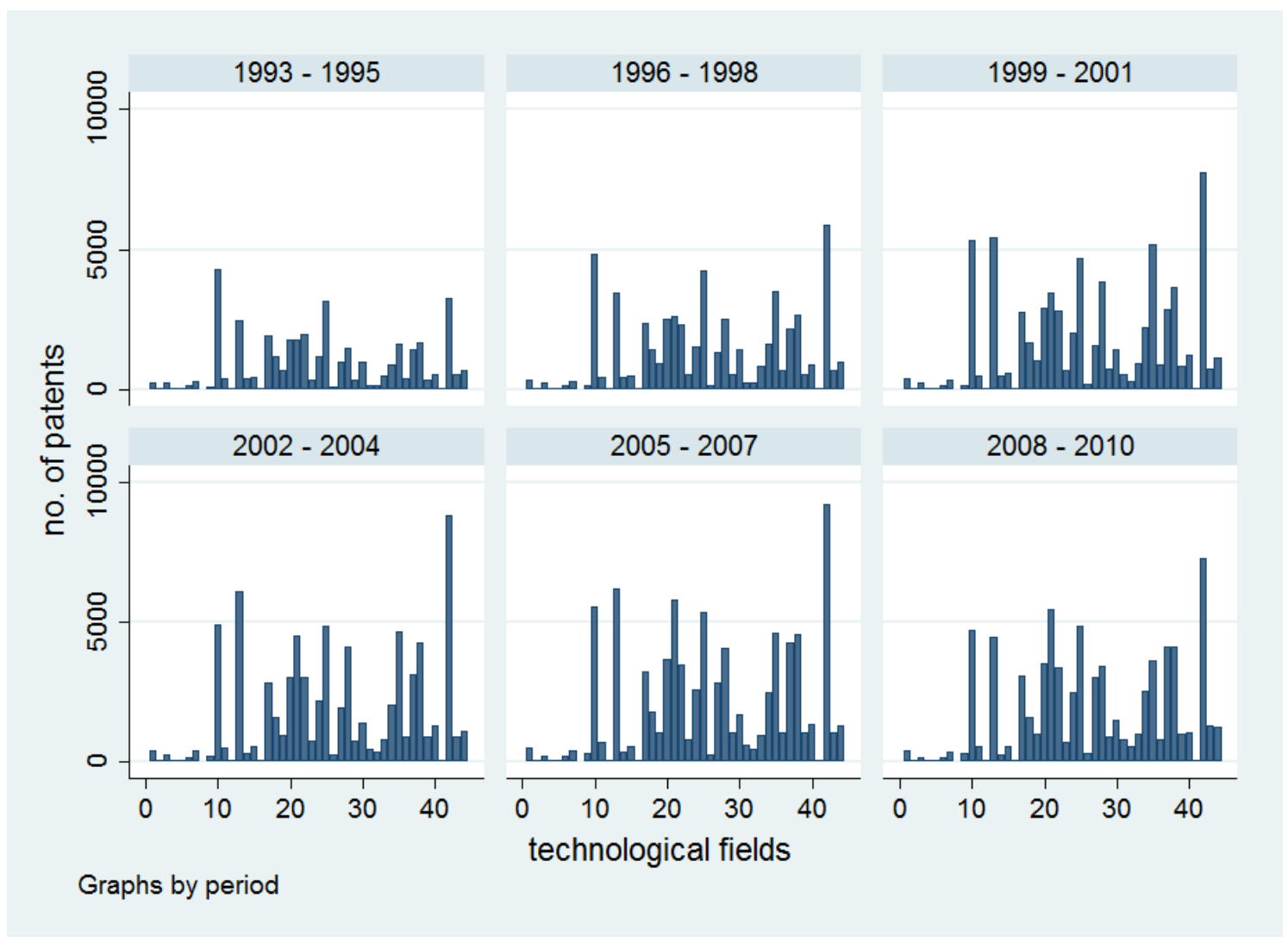

Source: REGPAT database, own calculation. 
APPENDIX 6: Patent application and co-application distribution by technological fields

\begin{tabular}{|c|c|c|c|c|c|c|c|c|}
\hline \multirow[b]{3}{*}{ Period } & \multicolumn{8}{|c|}{ East Germany } \\
\hline & \multicolumn{2}{|c|}{ Patent applications } & \multicolumn{2}{|c|}{ Co-application } & \multicolumn{4}{|c|}{ Cooperation propensity } \\
\hline & Number & $\begin{array}{l}\text { Gini coeff. } \\
\text { techn. fields }\end{array}$ & Number & $\begin{array}{l}\text { Gini coeff. } \\
\text { techn. fields }\end{array}$ & Min & Max & Mean & $\begin{array}{l}\text { Gini coeff. } \\
\text { techn. fields }\end{array}$ \\
\hline $1993-1995$ & 1106 & .538 & 103 & .484 & .022 & .923 & .144 & .481 \\
\hline $1996-1998$ & 2001 & .555 & 188 & .506 & .015 & .758 & .125 & .400 \\
\hline $1999-2001$ & 3229 & .578 & 301 & .577 & .016 & .344 & .114 & .308 \\
\hline $2002-2004$ & 3665 & .566 & 270 & .522 & .013 & .552 & .098 & .431 \\
\hline $2005-2007$ & 4659 & .538 & 300 & .503 & .021 & .211 & .067 & .270 \\
\hline \multirow[t]{2}{*}{$2008-2010$} & 4525 & .551 & 349 & .563 & .018 & .306 & .084 & .284 \\
\hline & \multicolumn{8}{|c|}{ West Germany } \\
\hline \multirow[b]{2}{*}{ Period } & \multicolumn{2}{|c|}{ Patent applications } & \multicolumn{2}{|c|}{ Co-application } & \multicolumn{4}{|c|}{ Cooperation propensity } \\
\hline & Number & $\begin{array}{l}\text { Gini coeff. } \\
\text { techn. fields }\end{array}$ & Number & $\begin{array}{l}\text { Gini coeff. } \\
\text { techn. fields }\end{array}$ & Min & Max & Mean & $\begin{array}{l}\text { Gini coeff. } \\
\text { techn. fields }\end{array}$ \\
\hline $1993-1995$ & 38300 & .546 & 2005 & .517 & .007 & .123 & .054 & .258 \\
\hline $1996-1998$ & 54646 & .550 & 2662 & .544 & .014 & .105 & .050 & .197 \\
\hline $1999-2001$ & 68849 & .561 & 3162 & .562 & .024 & .114 & .050 & .220 \\
\hline $2002-2004$ & 72550 & .567 & 3288 & .621 & .013 & .145 & .047 & .290 \\
\hline $2005-2007$ & 81414 & .556 & 3831 & .606 & .015 & .132 & .048 & .312 \\
\hline
\end{tabular}




\begin{tabular}{|l|l|l|l|l|l|l|l|l|}
\hline $2008-2010$ & 72438 & .539 & 3266 & .587 & .017 & .133 & .045 & .278 \\
\hline
\end{tabular}

Source: REGPAT database, own calculation.

APPENDIX 7: Number of patent applications by planning regions (ROR).

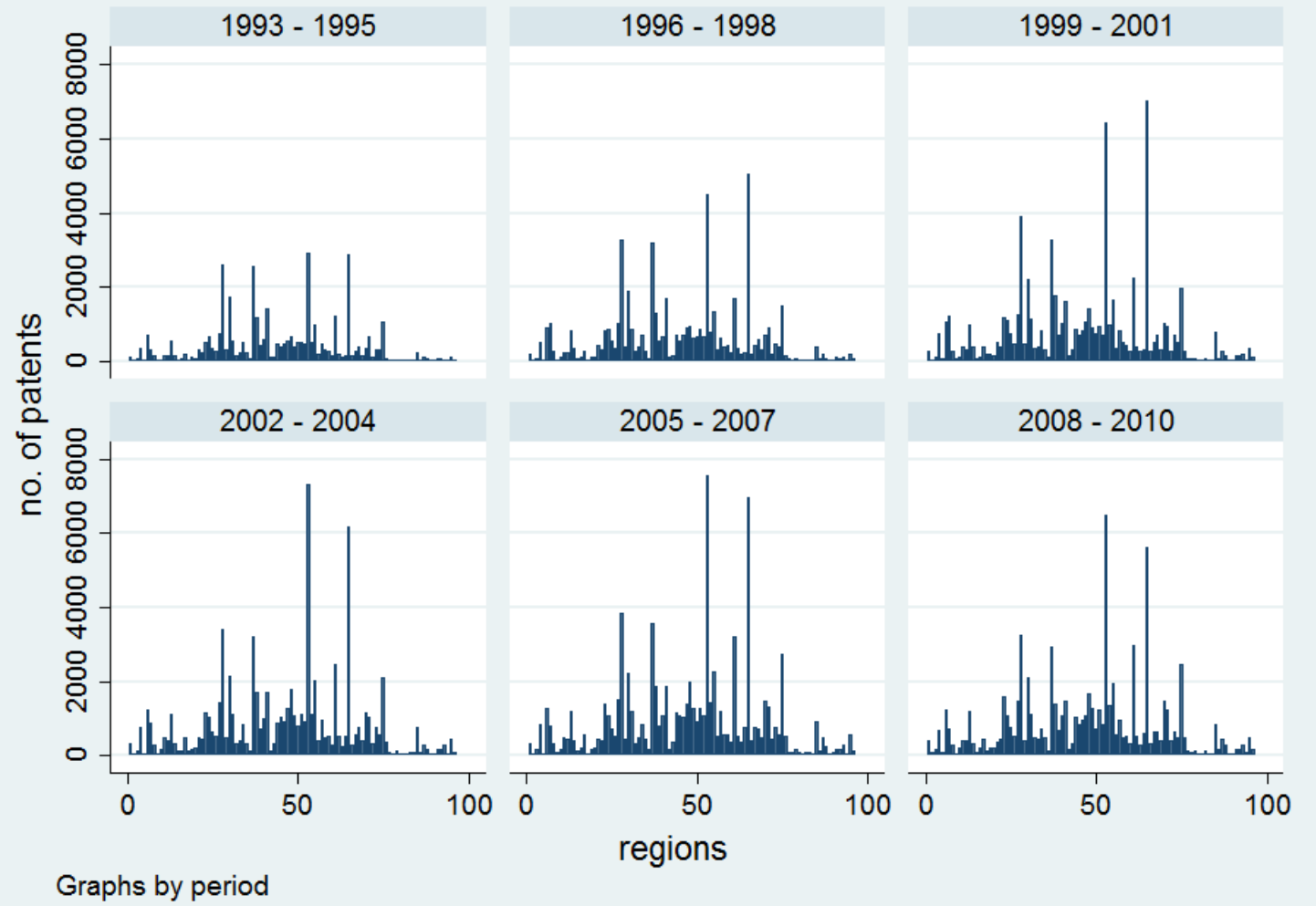

Source: REGPAT database, own calculation.

APPENDIX 8: Patent application and co-application distribution by planning regions (ROR)

\begin{tabular}{|c|c|c|c|c|c|c|c|c|}
\hline \multirow{3}{*}{ Period } & \multicolumn{4}{|c|}{ East Germany } & \multicolumn{4}{c|}{ West Germany } \\
\cline { 2 - 9 } & \multicolumn{2}{|c|}{ Patent applications } & \multicolumn{2}{|c|}{ Co-applications } & \multicolumn{2}{c|}{ Patent applications } & \multicolumn{2}{c|}{ Co-applications } \\
\cline { 2 - 9 } & Number & $\begin{array}{c}\text { Gini coeff. } \\
\text { ROR }\end{array}$ & Number & $\begin{array}{c}\text { Gini coeff. } \\
\text { ROR }\end{array}$ & Number & $\begin{array}{c}\text { Gini coeff. } \\
\text { ROR }\end{array}$ & Number & $\begin{array}{c}\text { Gini coeff. } \\
\text { ROR }\end{array}$ \\
\hline $1993-1995$ & 1106 & .495 & 103 & .483 & 38300 & .528 & 2005 & .574 \\
\hline $1996-1998$ & 2001 & .471 & 188 & .475 & 54646 & .519 & 2662 & .533 \\
\hline $1999-2001$ & 3229 & .496 & 301 & .503 & 68849 & .518 & 3162 & .537 \\
\hline $2002-2004$ & 3665 & .478 & 270 & .478 & 72550 & .501 & 3288 & .536 \\
\hline
\end{tabular}




\begin{tabular}{|c|c|c|c|c|c|c|c|c|}
\hline $2005-2007$ & 4659 & .472 & 300 & .460 & 81414 & .500 & 3831 & .548 \\
\hline $2008-2010$ & 4525 & .452 & 349 & .490 & 72438 & .484 & 3266 & .534 \\
\hline
\end{tabular}

Source: REGPAT database, own calculation.

APPENDIX 9: "Convergence" of RRI values in East and West over time

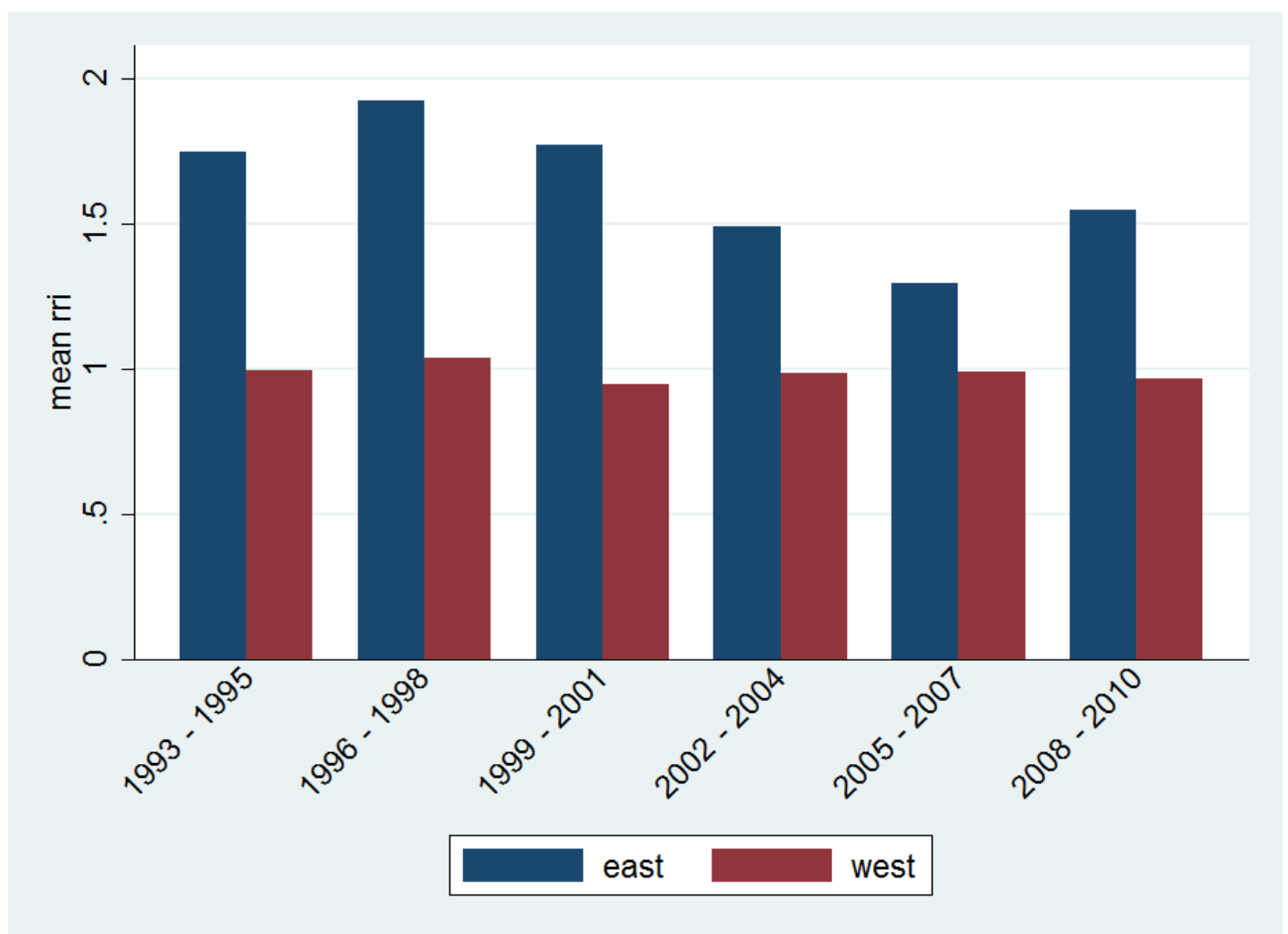

Source: REGPAT database, own calculation. 
APPENDIX 10: RRI distribution by planning regions (ROR)

\begin{tabular}{|c|c|c|c|c|c|c|c|c|}
\hline & \multicolumn{5}{|c|}{ East Germany } & \multicolumn{3}{c|}{ West Germany } \\
\hline Period & Min & Max & Mean & Gini coeff. & Min & Max & Mean & Gini coeff. \\
& & & & ROR & & & & \\
\hline $1993-1995$ & 0.000 & 3.383 & 1.745 & 0.254 & 0.000 & 5.925 & 0.996 & 0.295 \\
\hline $1996-1998$ & 0.473 & 3.924 & 1.921 & 0.246 & 0.391 & 5.340 & 1.038 & 0.230 \\
\hline $1999-2001$ & 0.895 & 3.525 & 1.768 & 0.166 & 0.058 & 1.962 & 0.946 & 0.180 \\
\hline $2002-2004$ & 0.645 & 2.444 & 1.490 & 0.188 & 0.358 & 3.188 & 0.988 & 0.211 \\
\hline $2005-2007$ & 0.643 & 2.172 & 1.294 & 0.178 & 0.369 & 3.036 & 0.989 & 0.236 \\
\hline $2008-2010$ & 0.488 & 4.296 & 1.549 & 0.227 & 0.256 & 2.128 & 0.965 & 0.207 \\
\hline
\end{tabular}

Source: REGPAT database, own calculation 
APPENDIX 11: RRI values in East and West Germany (alternative illustration)

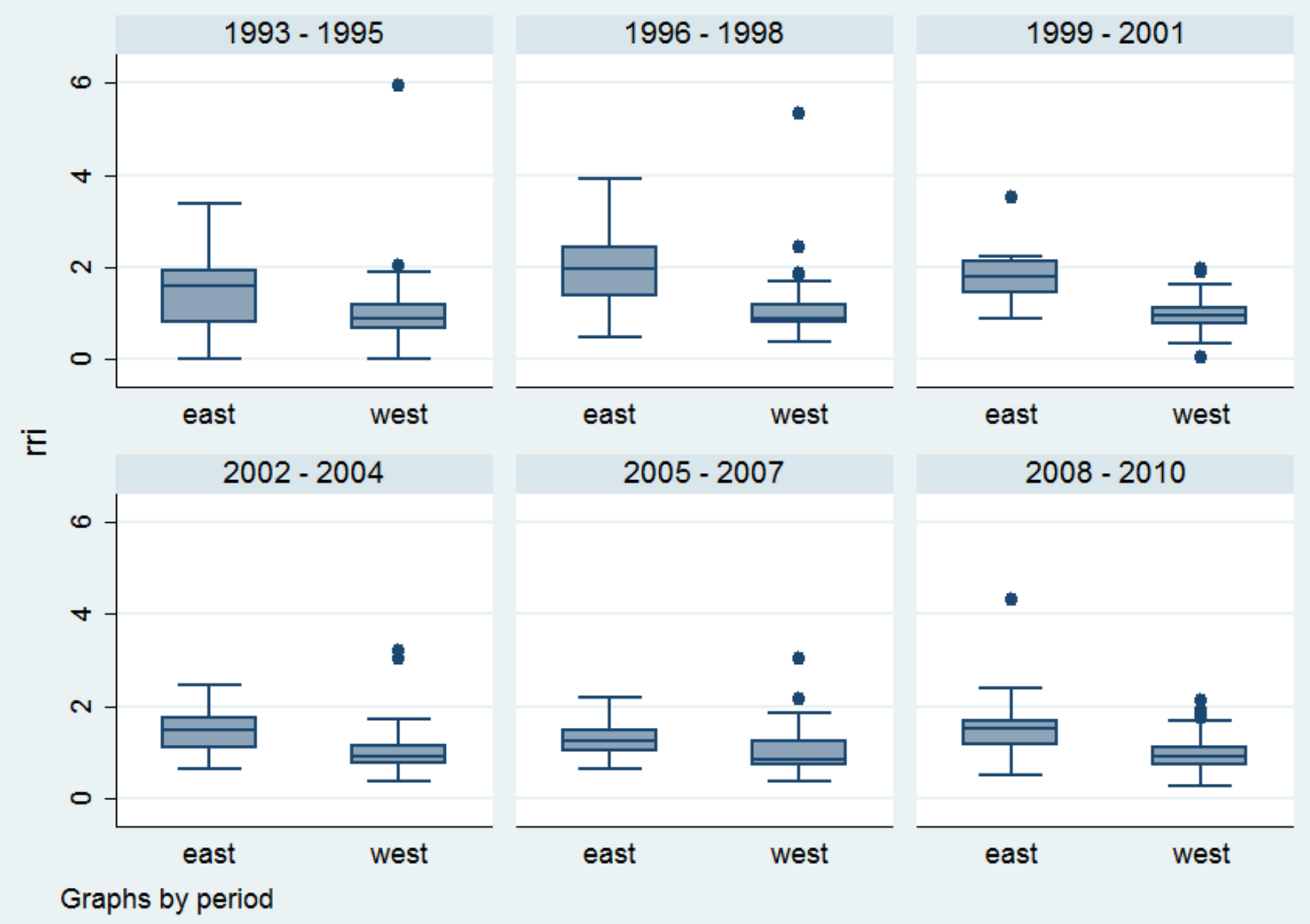

Source: REGPAT database, own calculation 
APPENDIX 12: RRI index for German regions 1996-1998, 1999-2001, 2002-2004, 2005-
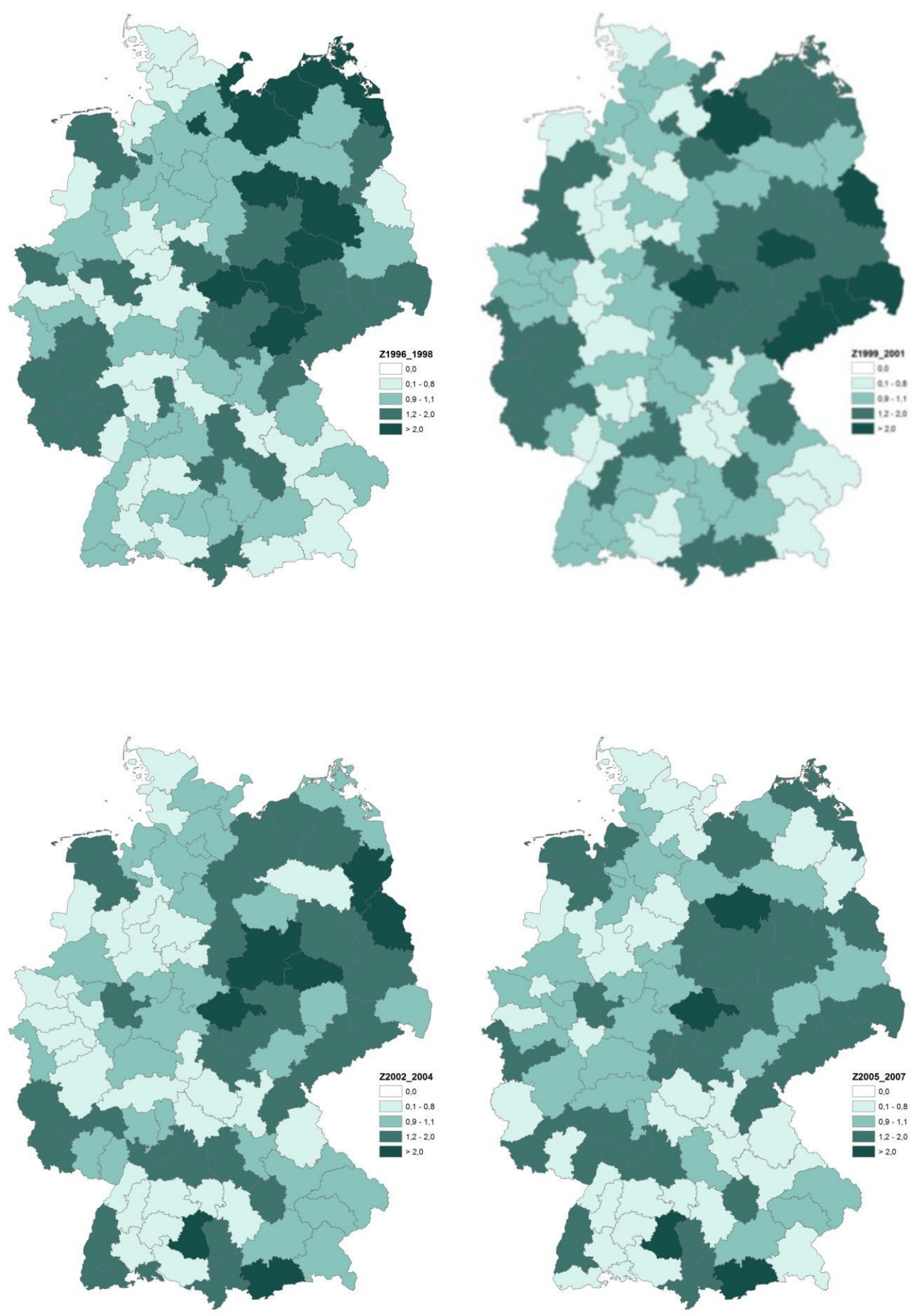

Source: REGPAT database, own calculation 
APPENDIX 13: Correlation between size of a region (number of patents) and RRI value

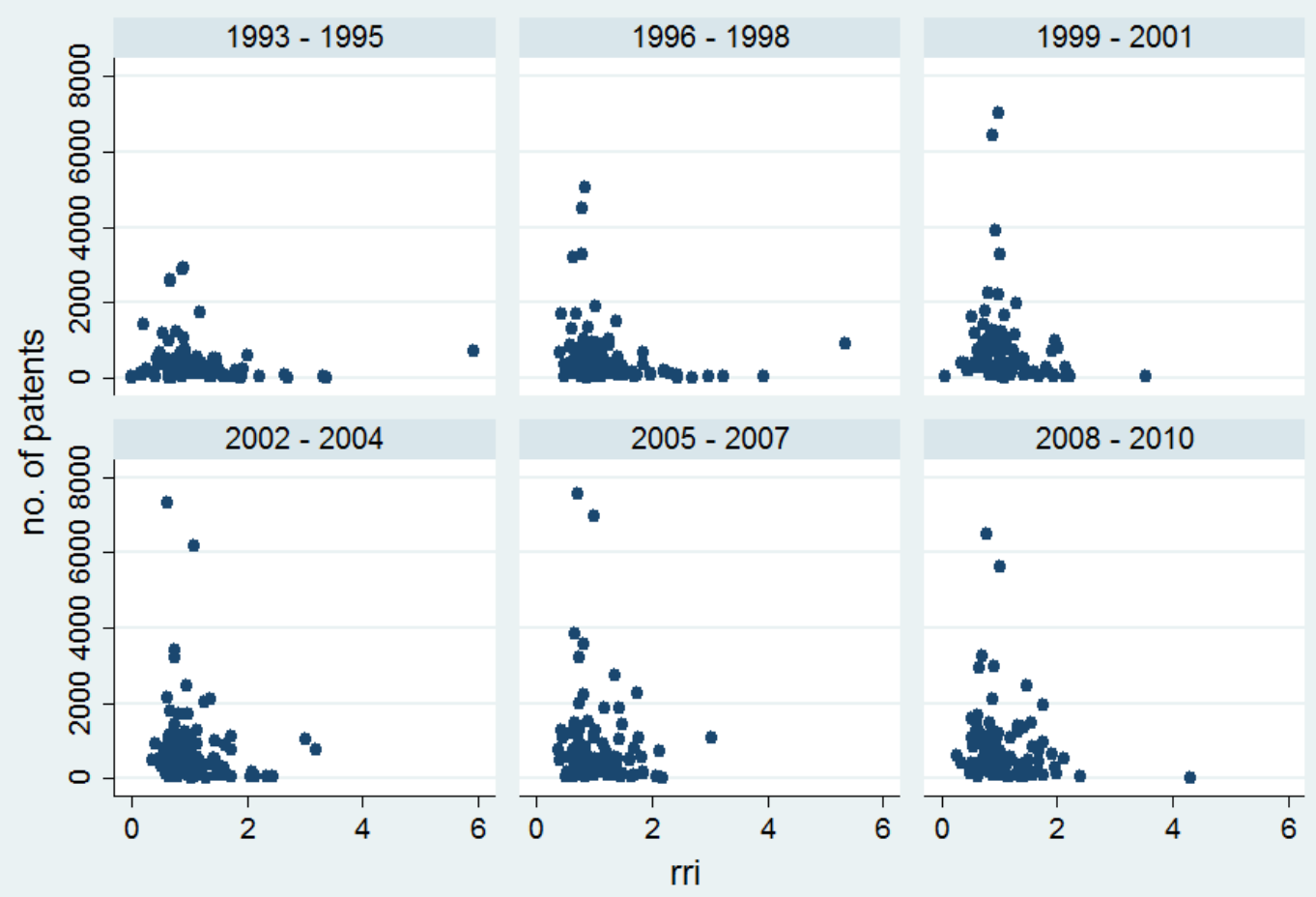

Graphs by period

Source: REGPAT database, own calculation 
APPENDIX 14: Mean RRI values per region

\begin{tabular}{|c|c|c|c|c|c|}
\hline $\begin{array}{l}\text { ROR } \\
\text { No. }\end{array}$ & Name of ROR & RRI mean & $\begin{array}{l}\text { ROR } \\
\text { No. }\end{array}$ & Name of ROR & RRI mean \\
\hline 101 & Schleswig-Holstein Mitte & $0.855132 *$ & 806 & Neckar-Alb & 0.802653 \\
\hline 102 & Schleswig-Holstein Nord & $0.571462 *$ & 807 & Nordschwarzwald & $0.856301 *$ \\
\hline 103 & Schleswig-Holstein Ost & 1.321696 & 808 & Ostwürttemberg & 0.957694 \\
\hline 104 & Schleswig-Holstein Süd & $0.839078 * *$ & 809 & Schwarzwald-Baar-Heuberg & $0.532515 * * *$ \\
\hline 105 & $\begin{array}{l}\text { Schlesw.-Holst. Süd- } \\
\text { West }\end{array}$ & 0.915747 & 810 & Stuttgart & $0.783649 * * *$ \\
\hline 201 & Hamburg & 2.604984 & 811 & Südlicher Oberrhein & $1.328857 * *$ \\
\hline 301 & Braunschweig & $1.350171^{*}$ & 812 & Unterer Neckar & 1.233678 \\
\hline 302 & Bremen-Umland & 0.932881 & 901 & Allgäu & $1.36054 * *$ \\
\hline 303 & Bremerhaven & 1.227942 & 902 & Augsburg & $0.766855^{* *}$ \\
\hline 304 & Emsland & $0.640486^{* *}$ & 903 & Bayerischer Untermain & 0.950162 \\
\hline 305 & Göttingen & 1.162545 & 904 & Donau-Iller (BY) & 1.188654 \\
\hline 306 & Hamburg-Umland-Süd & 0.956977 & 905 & Donau-Wald & $0.851096^{*}$ \\
\hline 307 & Hannover & $0.836005^{*}$ & 906 & Industrieregion Mittelfranken & $0.805384 * * *$ \\
\hline 308 & Hildesheim & $0.51862 * * *$ & 907 & Ingolstadt & $1.563962 * *$ \\
\hline 309 & Lüneburg & 1.014126 & 908 & Landshut & 0.83426 \\
\hline 310 & Oldenburg & 1.004051 & 909 & Main-Rhön & $0.561636^{* *}$ \\
\hline 311 & Osnabrück & $0.619538^{* *}$ & 910 & München & 0.967602 \\
\hline 312 & Ost-Friesland & 1.294971 & 911 & Oberfranken-Ost & 1.108736 \\
\hline 313 & Südheide & $0.616825 * *$ & 912 & Oberfranken-West & $0.772919 * * *$ \\
\hline 401 & Bremen & 1.203486 & 913 & Oberland & $1.792386^{*}$ \\
\hline 501 & Aachen & $1.211074^{*}$ & 914 & Oberpfalz-Nord & $0.624156^{*}$ \\
\hline 502 & Arnsberg & 1.085688 & 915 & Regensburg & $0.689716^{* * *}$ \\
\hline 503 & Bielefeld & $0.588893 * * *$ & 916 & Südostoberbayern & $0.722694 * *$ \\
\hline 504 & Bochum/Hagen & $0.871837 * *$ & 917 & Westmittelfranken & 0.871374 \\
\hline 505 & Bonn & 1.068262 & 918 & Würzburg & $0.794786 * * *$ \\
\hline 506 & Dortmund & 1.106714 & 1001 & Saar & $1.271693 * *$ \\
\hline
\end{tabular}




\begin{tabular}{|c|c|c|c|c|c|}
\hline 507 & Duisburg/Essen & 0.922335 & 1101 & Berlin & 1.292613 \\
\hline 508 & Düsseldorf & $0.753224 * * *$ & 1201 & Havelland-Fläming & 1.391142 \\
\hline 509 & Emscher-Lippe & 0.873854 & 1202 & Lausitz-Spreewald & $1.286372 *$ \\
\hline 510 & Köln & 0.916339 & 1203 & Oderland-Spree & 1.508711 \\
\hline 511 & Münster & 0.976888 & 1204 & Prignitz-Oberhavel & $0.773352 * *$ \\
\hline 512 & Paderborn & $0.823752 * *$ & 1205 & Uckermark-Barnim & 1.122908 \\
\hline 513 & Siegen & $0.692223 * *$ & 1301 & Mecklenburgische Seenplatte & 0.845751 \\
\hline 601 & Mittelhessen & $0.794817 * * *$ & 1302 & Mittleres Mecklenburg/Rostock & $1.960988 * *$ \\
\hline 602 & Nordhessen & $0.791704 * *$ & 1303 & Vorpommern & $2.120242 * *$ \\
\hline 603 & Osthessen & 1.114883 & 1304 & Westmecklenburg & $2.2778 * *$ \\
\hline 604 & Rhein-Main & $0.758093 * * *$ & 1401 & Oberes Elbtal/Osterzgebirge & $1.626803 * * *$ \\
\hline 605 & Starkenburg & 0.937197 & 1402 & Oberlausitz-Niederschlesien & 1.284393 \\
\hline 701 & Mittelrhein-Westerwald & 1.031349 & 1403 & Südsachsen & $1.642726^{* * *}$ \\
\hline 702 & Rheinhessen-Nahe & $1.699505 * * *$ & 1404 & Westsachsen & 1.531486 \\
\hline 703 & Rheinpfalz & 0.784849 & 1501 & Altmark & 1.881157 \\
\hline 704 & Trier & 0.946807 & 1502 & Anhalt-Bitterfeld-Wittenberg & $1.886235 * * *$ \\
\hline 705 & Westpfalz & 1.137205 & 1503 & Halle/S. & $1.59391 * *$ \\
\hline 801 & Bodensee-Oberschwaben & $0.677096^{* * *}$ & 1504 & Magdeburg & $1.677484 * * *$ \\
\hline 802 & Donau-Iller (BW) & 1.598939 & 1601 & Mittelthüringen & $1.739575 * * *$ \\
\hline 803 & Franken & $1.250257^{*}$ & 1602 & Nordthüringen & $2.476837 * *$ \\
\hline 804 & Hochrhein-Bodensee & 0.925859 & 1603 & Ostthüringen & $1.42644 *$ \\
\hline 805 & Mittlerer Oberrhein & $0.764825 * * *$ & 1604 & Südthüringen & $1.553665^{* * *}$ \\
\hline
\end{tabular}

Source: REGPAT database, own calculation

Note: Significance level of $* * *-99 \%, * *-95 \%$ or $*-90 \%$ (t test) 
APPENDIX 15: Robustness check

Findings using 8 IPC main technology classes

a) Descriptive statistics

\begin{tabular}{|l|c|c|c|c|c|c|c|c|c|}
\hline \multirow{2}{*}{ Time period } & \multicolumn{2}{|c|}{ Number of patent applications } & \multicolumn{2}{c|}{ Number of cooperative patent } & \multicolumn{3}{c|}{ Cooperative patent } \\
& & & \multicolumn{2}{|c|}{ applications } & \multicolumn{3}{c|}{ applications (\%) } \\
\hline & Total & East & West & Total & East & West & Total & East & West \\
\hline $1993-1995$ & 39689.01 & 1160.47 & 38528.54 & 2154.47 & 108.39 & 2046.09 & 5.43 & 9.34 & 5.31 \\
\hline $1996-1998$ & 57310.17 & 2080.83 & 55229.34 & 2932.05 & 199.71 & 2732.34 & 5.12 & 9.60 & 4.95 \\
\hline $1999-2001$ & 73240.40 & 3363.81 & 69876.59 & 3579.32 & 311.97 & 3267.35 & 4.89 & 9.27 & 4.68 \\
\hline $2002-2004$ & 77721.84 & 3817.98 & 73903.85 & 3708.11 & 286.02 & 3422.10 & 4.77 & 7.49 & 4.63 \\
\hline $2005-2007$ & 88228.70 & 4864.60 & 83364.09 & 4291.19 & 323.81 & 3967.38 & 4.86 & 6.66 & 4.76 \\
\hline $2008-2010$ & 78943.91 & 4704.53 & 74239.38 & 3789.51 & 368.39 & 3421.12 & 4.80 & 7.83 & 4.61 \\
\hline
\end{tabular}

b) RRI values of East and West German regions over time

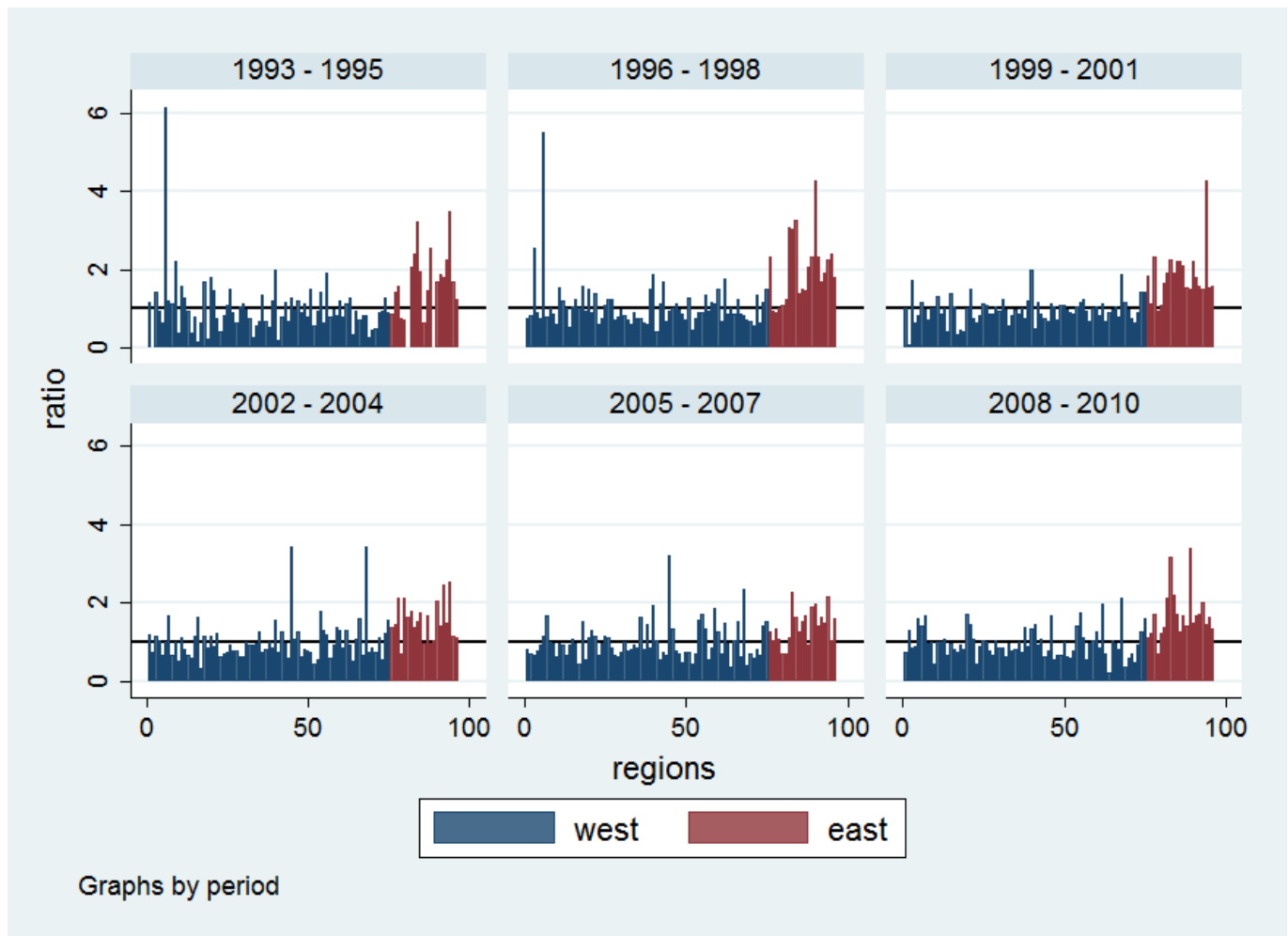

RRI variance East: 0.349

RRI variance West: 0.187 
c) RRI values in East and West German regions

\begin{tabular}{|c|c|c|c|c|c|c|}
\hline & \multicolumn{3}{|c|}{ East Germany } & \multicolumn{3}{c|}{ West Germany } \\
\hline Period & Min & Max & Mean & Min & Max & Mean \\
\hline $1993-1995$ & 0.000 & 3.467 & 1.767 & 0.000 & 6.157 & 1.016 \\
\hline $1996-1998$ & 0.882 & 4.265 & 2.008 & 0.424 & 5.505 & 1.058 \\
\hline $1999-2001$ & 0.938 & 4.274 & 1.859 & 0.062 & 1.975 & 0.954 \\
\hline $2002-2004$ & 0.712 & 2.545 & 1.555 & 0.333 & 3.426 & 1.005 \\
\hline $2005-2007$ & 0.683 & 2.274 & 1.409 & 0.376 & 3.213 & 0.994 \\
\hline $2008-2010$ & 0.688 & 3.505 & 1.690 & 0.227 & 2.124 & 0.970 \\
\hline
\end{tabular}

Findings using applicants as a basis for regionalization

a) Descriptive statistics

\begin{tabular}{|c|c|c|c|c|c|c|c|c|c|}
\hline \multirow{2}{*}{ Time period } & \multicolumn{2}{|c|}{ Number of patent applications } & \multicolumn{2}{c|}{ Number of cooperative patent } & \multicolumn{3}{c|}{ Cooperative patent } \\
& & & \multicolumn{2}{c}{ applications } & \multicolumn{3}{c|}{ applications (\%) } \\
\hline & Total & East & West & Total & East & West & Total & East & West \\
\hline $1993-1995$ & 39036.09 & 870.20 & 38165.89 & 2018.09 & 85.20 & 1932.89 & 5.17 & 9.79 & 5.06 \\
\hline $1996-1998$ & 56087.62 & 1468.66 & 54618.96 & 2892.62 & 187.66 & 2704.96 & 5.16 & 12.78 & 4.95 \\
\hline $1999-2001$ & 71903.33 & 2153.19 & 69750.13 & 3816.33 & 239.19 & 3577.13 & 5.31 & 11.11 & 5.13 \\
\hline $2002-2004$ & 75605.94 & 2425.53 & 73180.41 & 3960.94 & 224.53 & 3736.41 & 5.24 & 9.26 & 5.11 \\
\hline $2005-2007$ & 85209.27 & 2862.86 & 82346.41 & 4829.26 & 252.86 & 4576.41 & 5.67 & 8.83 & 5.56 \\
\hline $2008-2010$ & 76613.34 & 3076.30 & 73537.05 & 4205.34 & 289.30 & 3916.04 & 5.49 & 9.40 & 5.33 \\
\hline
\end{tabular}


b) RRI values of East and West German regions over time

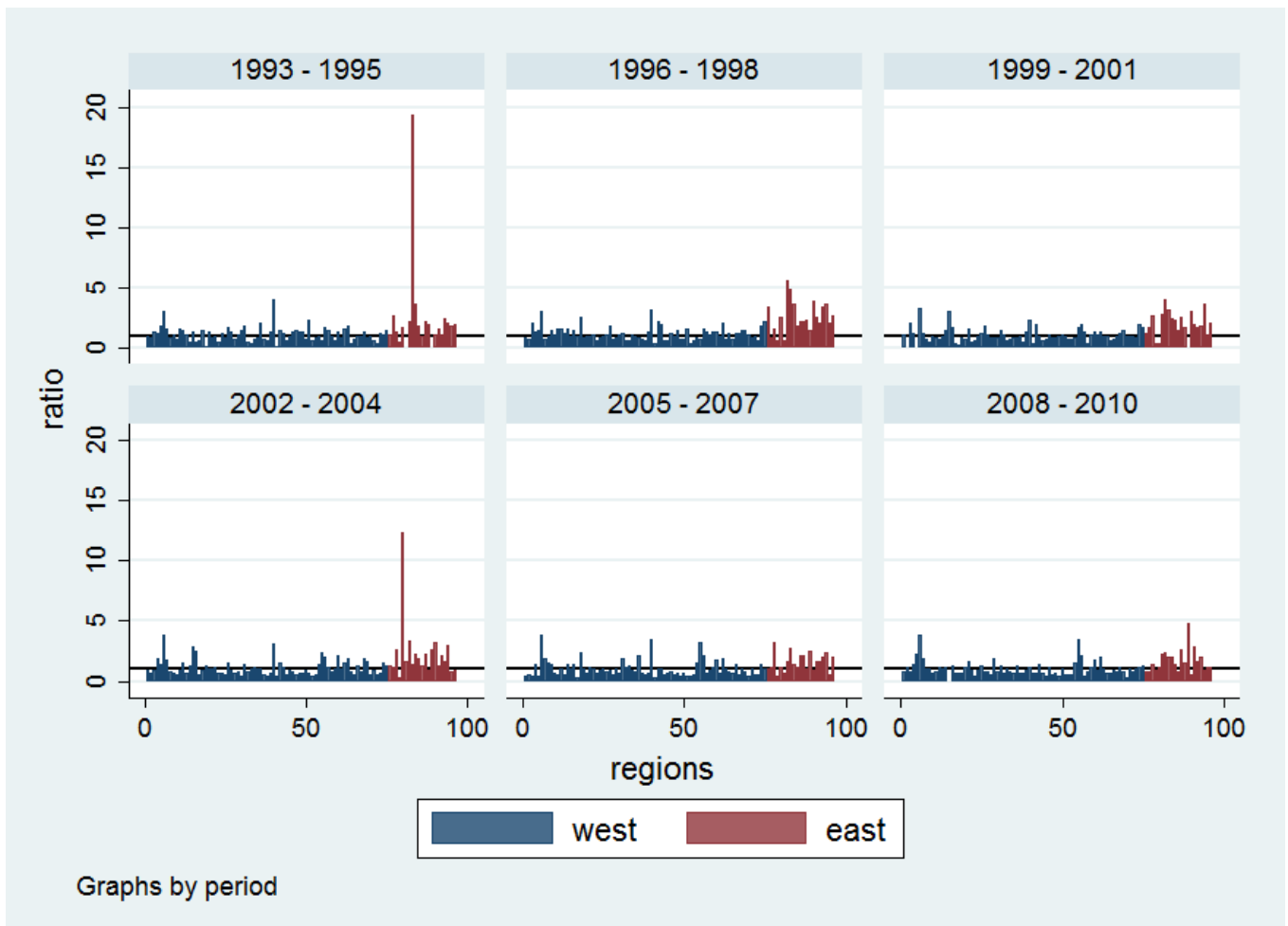

RRI variance East: 3,758

RRI variance West: 0,175

c) RRI values in East and West German regions

\begin{tabular}{|c|c|c|c|c|c|c|}
\hline & \multicolumn{3}{|c|}{ East Germany } & \multicolumn{3}{c|}{ West Germany } \\
\hline Period & Min & Max & Mean & Min & Max & Mean \\
\hline $1993-1995$ & 0.000 & 19.348 & 2.720 & 0.137 & 3.980 & 1.121 \\
\hline $1996-1998$ & 0.634 & 5.582 & 2.563 & 0.338 & 3.213 & 1.188 \\
\hline $1999-2001$ & 0.000 & 4.007 & 2.103 & 0.000 & 3.279 & 1.099 \\
\hline $2002-2004$ & 0.365 & 12.354 & 2.312 & 0.406 & 3.826 & 1.130 \\
\hline $2005-2007$ & 0.378 & 3.190 & 1.597 & 0.313 & 3.794 & 1.055 \\
\hline $2008-2010$ & 0.595 & 4.807 & 1.682 & 0.000 & 3.813 & 1.054 \\
\hline
\end{tabular}


i In our paper we are not talking about innovation networks, but deliberate cooperation, since there are substantial differences between these two concepts (for a discussion s. e.g. Günther 2004).

${ }^{i i}$ We assume that there is at least one innovation in each technology. Therefore, we do not distinguish several cases in equation 6.

iii In principle, we have two levels of empirical analysis, first of all planning regions (ROR) and second, East and West Germany, each consisting of a particular number of planning regions which can be compared to each other.

iv Since the data is normalized in this procedure, the coefficients between the two different variables can be compared.

${ }^{v}$ For an illustration see Appendix 9. In West Germany, the RRI value does not change much over time. In East Germany, an initially much higher value (close to 2) drops particularly between 1996 and 2007, and is close to 1.5 in 2008-2010 (see also Appendix 10).

${ }^{\text {vi }}$ For an alternative illustration (box plots), see Appendix 9.

vii The continuously high RRI values in the structurally weak North Eastern region (Vorpommern-Greifswald) are based on low numbers of patent applications and co-applications and should not be overestimated.

viii When using applicants for regionalisation, the total number of patents decreases in the East, which is a wellknown finding from the above mentioned literature. However, the number of co-patents does not decrease as strongly as patents leading to a higher share of co-patents, which in turn contributes to the observed higher level of RRI values. 